\title{
LEVEL II SCOUR ANALYSIS FOR BRIDGE 35 (ANDOVT00110035) on STATE ROUTE 11, crossing the MIDDLE BRANCH WILLIAMS RIVER, ANDOVER, VERMONT
}

Open-File Report 98-87

Prepared in cooperation with

VERMONT AGENCY OF TRANSPORTATION

and

FEDERAL HIGHWAY ADMINISTRATION

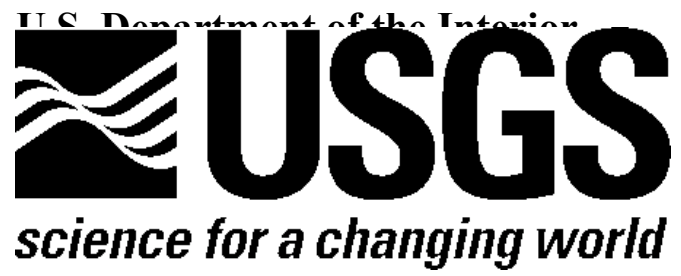




\section{LEVEL II SCOUR ANALYSIS FOR BRIDGE 35 (ANDOVT00110035) on STATE ROUTE 11, crossing the MIDDLE BRANCH WILLIAMS RIVER, ANDOVER, VERMONT \\ By RONDA L. BURNS and EMILY C. WILD}

U.S. Geological Survey Open-File Report 98-87

Prepared in cooperation with

VERMONT AGENCY OF TRANSPORTATION

and

FEDERAL HIGHWAY ADMINISTRATION 


\title{
U.S. DEPARTMENT OF THE INTERIOR BRUCE BABBITT, Secretary
}

\author{
U.S. GEOLOGICAL SURVEY
}

Thomas J. Casadevall, Acting Director

For additional information write to:

District Chief

U.S. Geological Survey 361 Commerce Way

Pembroke, NH 03275-3718
Copies of this report may be purchased from:

U.S. Geological Survey

Branch of Information Services

Open-File Reports Unit

Box 25286

Denver, CO 80225-0286 


\section{CONTENTS}

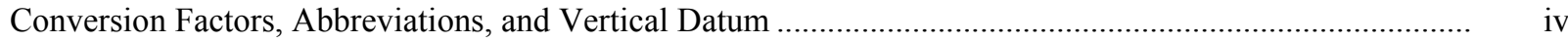

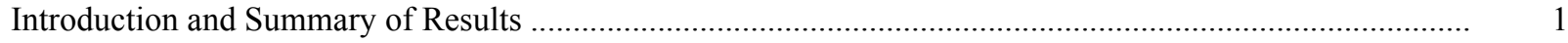

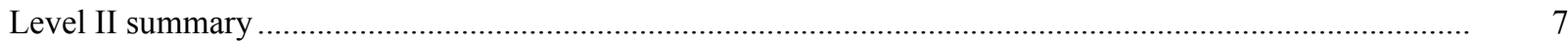

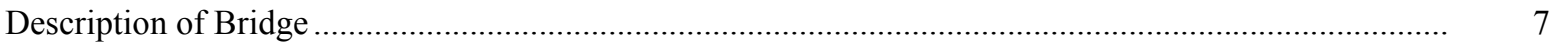

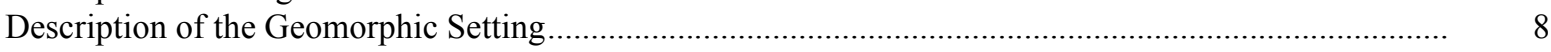

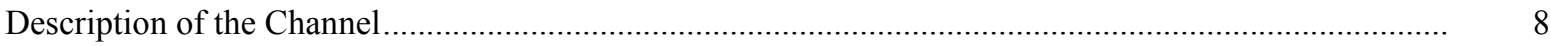

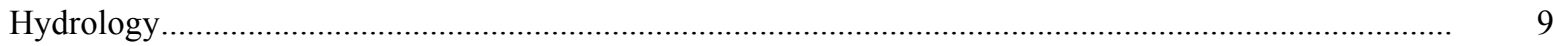

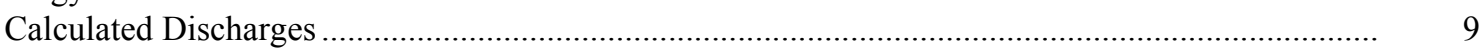

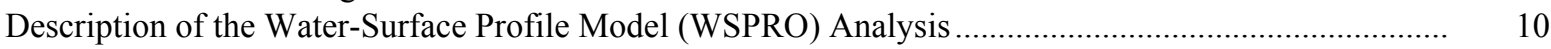

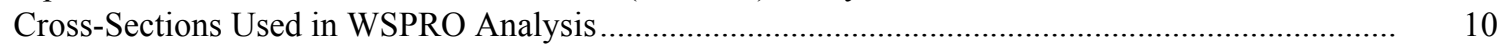

Data and Assumptions Used in WSPRO Model ........................................................................ 11

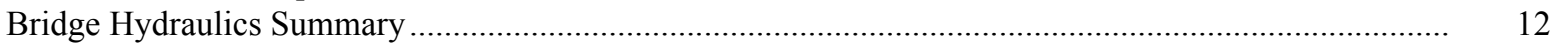

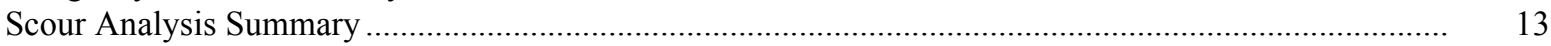

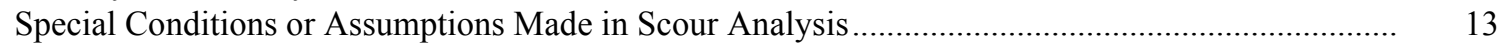

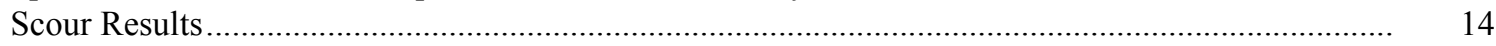

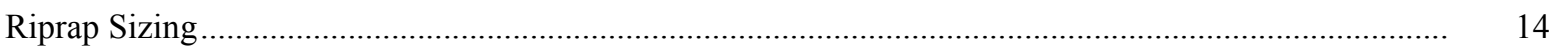

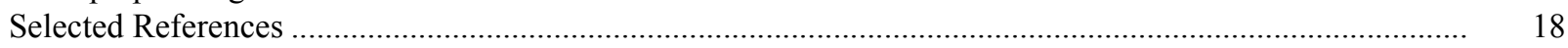

Appendices:

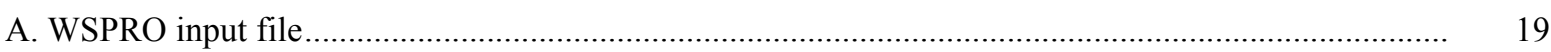

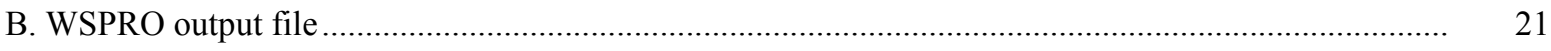

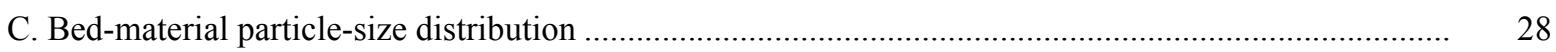

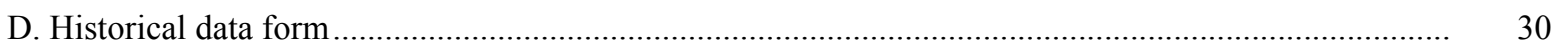

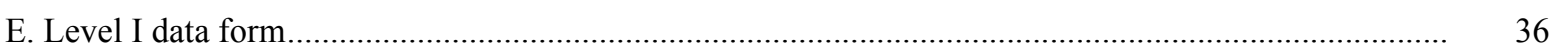

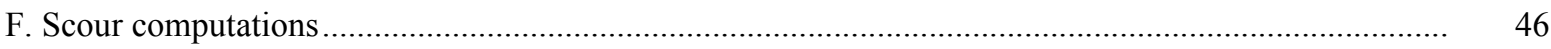

\section{FIGURES}

1. Map showing location of study area on USGS 1:25,000 scale map

2. Map showing location of study area on Vermont Agency of Transportation town highway map .....

3. Structure ANDOVT00110035 viewed from upstream (August 28, 1996)......

4. Downstream channel viewed from structure ANDOVT00110035 (August 28, 1996). ............................. 5

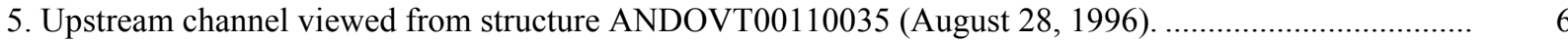

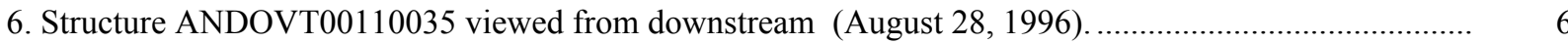

7. Water-surface profiles for the 100- and 500-year discharges at structure

ANDOVT00110035 on State Route 11, crossing the Middle Branch Williams River,

Andover, Vermont.

8. Scour elevations for the 100- and 500-year discharges at structure

ANDOVT00110035 on State Route 11, crossing the Middle Branch Williams River,

Andover, Vermont.

\section{TABLES}

1. Remaining footing/pile depth at abutments for the 100-year discharge at structure

ANDOVT00110035 on State Route 11, crossing the Middle Branch Williams River,

Andover, Vermont

2. Remaining footing/pile depth at abutments for the 500-year discharge at structure

ANDOVT00110035 on State Route 11, crossing the Middle Branch Williams River,

Andover, Vermont 


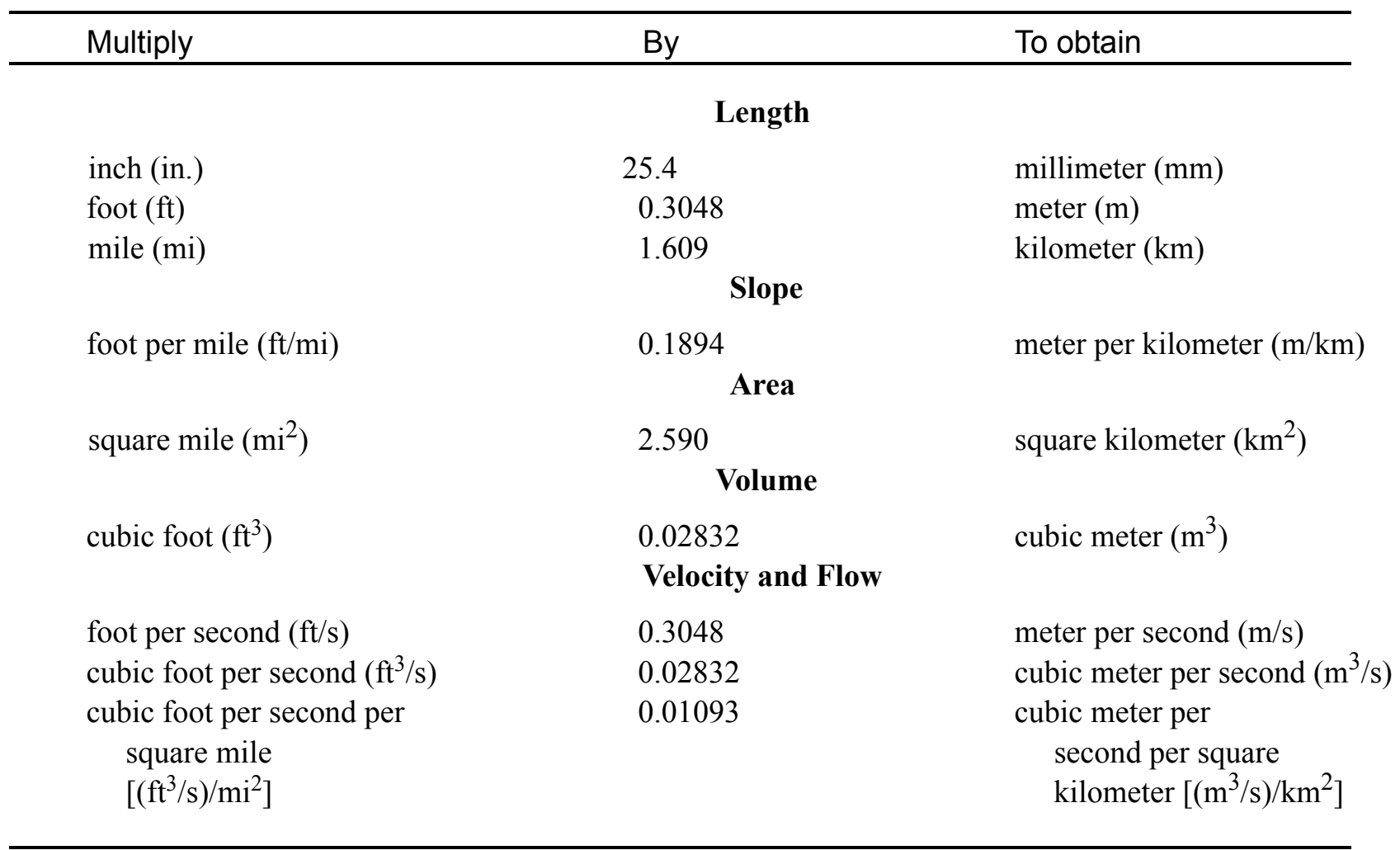

\section{OTHER ABBREVIATIONS}

$\begin{array}{lrlr}\text { BF } & \begin{array}{r}\text { bank full } \\ \text { cfs }\end{array} & \text { LWW } & \text { left wingwall } \\ \mathrm{D}_{50} & \text { median feet per second } & \text { Max } & \text { maximum } \\ \mathrm{DS} & \text { main channel } \\ \mathrm{elev} & \text { downstream } & \text { RAB } & \text { elevation } \\ \mathrm{f} / \mathrm{p} & \text { RABUT } & \text { right abutment } \\ \mathrm{ft} & \text { flood plain } & \text { RB } & \text { face of right abutment } \\ \mathrm{ft} / \mathrm{ft} & \text { square feet } & \text { ROB } & \text { right bank } \\ \text { FEMA } & \text { feet per foot } & \text { RWW } & \text { right overbank } \\ \text { FHWA } & \text { Federal Emergency Management Agency } & \text { TH } & \text { right wingwall } \\ \text { JCT } & \text { Federal Highway Administration } & \text { UB } & \text { town highway } \\ \text { LAB } & \text { junction } & \text { US } & \text { under bridge } \\ \text { LABUT } & \text { left abutment } & \text { USGS } & \text { upstream } \\ \text { LB } & \text { face of left abutment } & \text { VTAOT } & \text { Vermont Agency of Transportation } \\ \text { LOB } & \text { left bank } & \text { WSPRO } & \text { water-surface profile model } \\ & \text { left overbank } & \text { yr } & \text { year }\end{array}$

In this report, the words "right" and "left" refer to directions that would be reported by an observer facing downstream. Sea level: In this report, "sea level" refers to the National Geodetic Vertical Datum of 1929-- a geodetic datum derived from a general adjustment of the first-order level nets of the United States and Canada, formerly called Sea Level Datum of 1929.

In the appendices, the above abbreviations may be combined. For example, USLB would represent upstream left bank. 


\title{
LEVEL II SCOUR ANALYSIS FOR BRIDGE 35 (ANDOVT00110035) ON STATE ROUTE 11, CROSSING THE MIDDLE BRANCH WILLIAMS RIVER, ANDOVER, VERMONT
}

\author{
By Ronda L. Burns and Emily C. Wild
}

\section{INTRODUCTION AND SUMMARY OF RESULTS}

This report provides the results of a detailed Level II analysis of scour potential at structure ANDOVT00110035 on State Route 11 crossing the Middle Branch Williams River, Andover, Vermont (figures 1-8). A Level II study is a basic engineering analysis of the site, including a quantitative analysis of stream stability and scour (Federal Highway Administration, 1993). Results of a Level I scour investigation also are included in appendix $\mathrm{E}$ of this report. A Level I investigation provides a qualitative geomorphic characterization of the study site. Information on the bridge, gleaned from Vermont Agency of Transportation (VTAOT) files, was compiled prior to conducting Level I and Level II analyses and is found in appendix D.

The site is in the Green Mountain section of the New England physiographic province in south-central Vermont. The $4.65-\mathrm{mi}^{2}$ drainage area is in a predominantly rural and forested basin. In the vicinity of the study site, the surface cover is forest on the left bank and small trees and brush on the right bank upstream and downstream of the bridge.

In the study area, the Middle Branch Williams River has an incised, meandering channel with a slope of approximately $0.02 \mathrm{ft} / \mathrm{ft}$, an average channel top width of $57 \mathrm{ft}$ and an average bank height of $4 \mathrm{ft}$. The channel bed material ranges from gravel to boulder with a median grain size $\left(\mathrm{D}_{50}\right)$ of $31.4 \mathrm{~mm}(0.103 \mathrm{ft})$. The geomorphic assessment at the time of the Level I and Level II site visit on August 28, 1996, indicated that the reach was laterally unstable. There are cut-banks upstream and downstream of the bridge and an island in the channel upstream.

The State Route 11 crossing of the Middle Branch Williams River is a 28-ft-long, two-lane bridge consisting of one 24-ft concrete tee-beam span (Vermont Agency of Transportation, written communication, March 28, 1995). The opening length of the structure parallel to the bridge face is $23.6 \mathrm{ft}$. The bridge is supported by vertical, concrete abutments with wingwalls. The channel is skewed approximately 45 degrees to the opening while the computed opening-skew-to-roadway is 25 degrees. 
A scour hole ranging from 1.5 to $1.75 \mathrm{ft}$ deeper than the mean thalweg depth was observed along the upstream left wingwall, the left abutment, and the downstream left wingwall during the Level I assessment. The scour countermeasures at the site included type- 1 stone fill (less than 12 inches diameter) at the right road approach upstream and downstream of the bridge and type-2 stone fill (less than 36 inches diameter) at the left road approach upstream and downstream of the bridge. Additional details describing conditions at the site are included in the Level II Summary and appendices D and E.

Scour depths and recommended rock rip-rap sizes were computed using the general guidelines described in Hydraulic Engineering Circular 18 (Richardson and Davis, 1995) for the 100- and 500-year discharges. In addition, the incipient roadway-overtopping discharge was determined and analyzed as another potential worst-case scour scenario. Total scour at a highway crossing is comprised of three components: 1) long-term streambed degradation; 2) contraction scour (due to accelerated flow caused by a reduction in flow area at a bridge) and; 3 ) local scour (caused by accelerated flow around piers and abutments). Total scour is the sum of the three components. Equations are available to compute depths for contraction and local scour and a summary of the results of these computations follows.

Contraction scour for all modelled flows ranged from 2.0 to $4.3 \mathrm{ft}$. The worst-case contraction scour occurred at the 500-year discharge. Abutment scour ranged from 14.4 to $16.5 \mathrm{ft}$ at the left abutment and from 6.3 to $8.8 \mathrm{ft}$ at the right abutment. The worst-case abutment scour occurred at the 500-year discharge. Additional information on scour depths and depths to armoring are included in the section titled "Scour Results". Scouredstreambed elevations, based on the calculated scour depths, are presented in tables 1 and 2. A cross-section of the scour computed at the bridge is presented in figure 8. Scour depths were calculated assuming an infinite depth of erosive material and a homogeneous particlesize distribution.

It is generally accepted that the Froehlich equation (abutment scour) gives "excessively conservative estimates of scour depths" (Richardson and Davis, 1995, p. 46). Usually, computed scour depths are evaluated in combination with other information including (but not limited to) historical performance during flood events, the geomorphic stability assessment, existing scour protection measures, and the results of the hydraulic analyses. Therefore, scour depths adopted by VTAOT may differ from the computed values documented herein. 


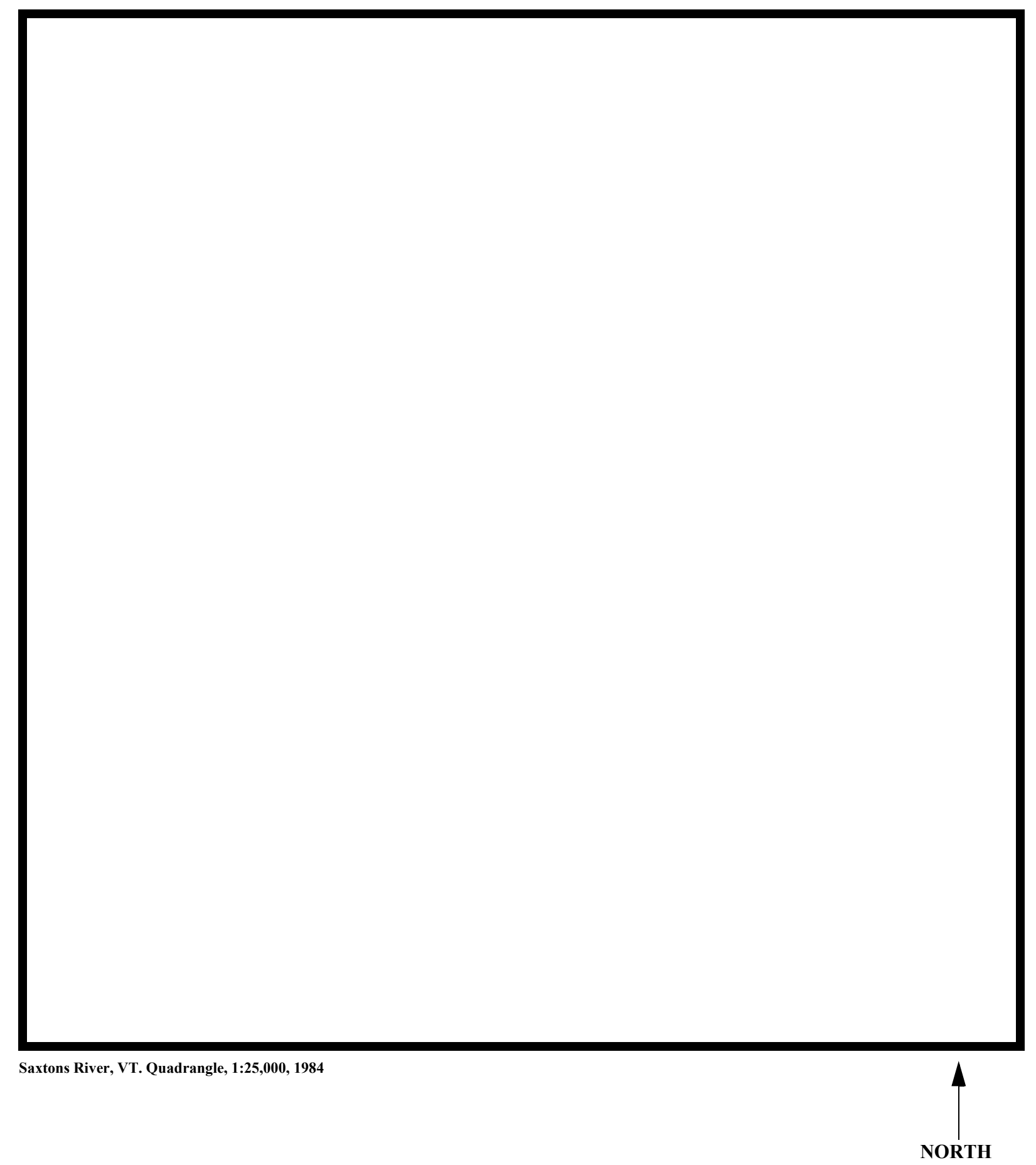

Figure 1. Location of study area on USGS 1:25,000 scale map. 
Figure 2. Location of study area on Vermont Agency of Transportation town highway map. 

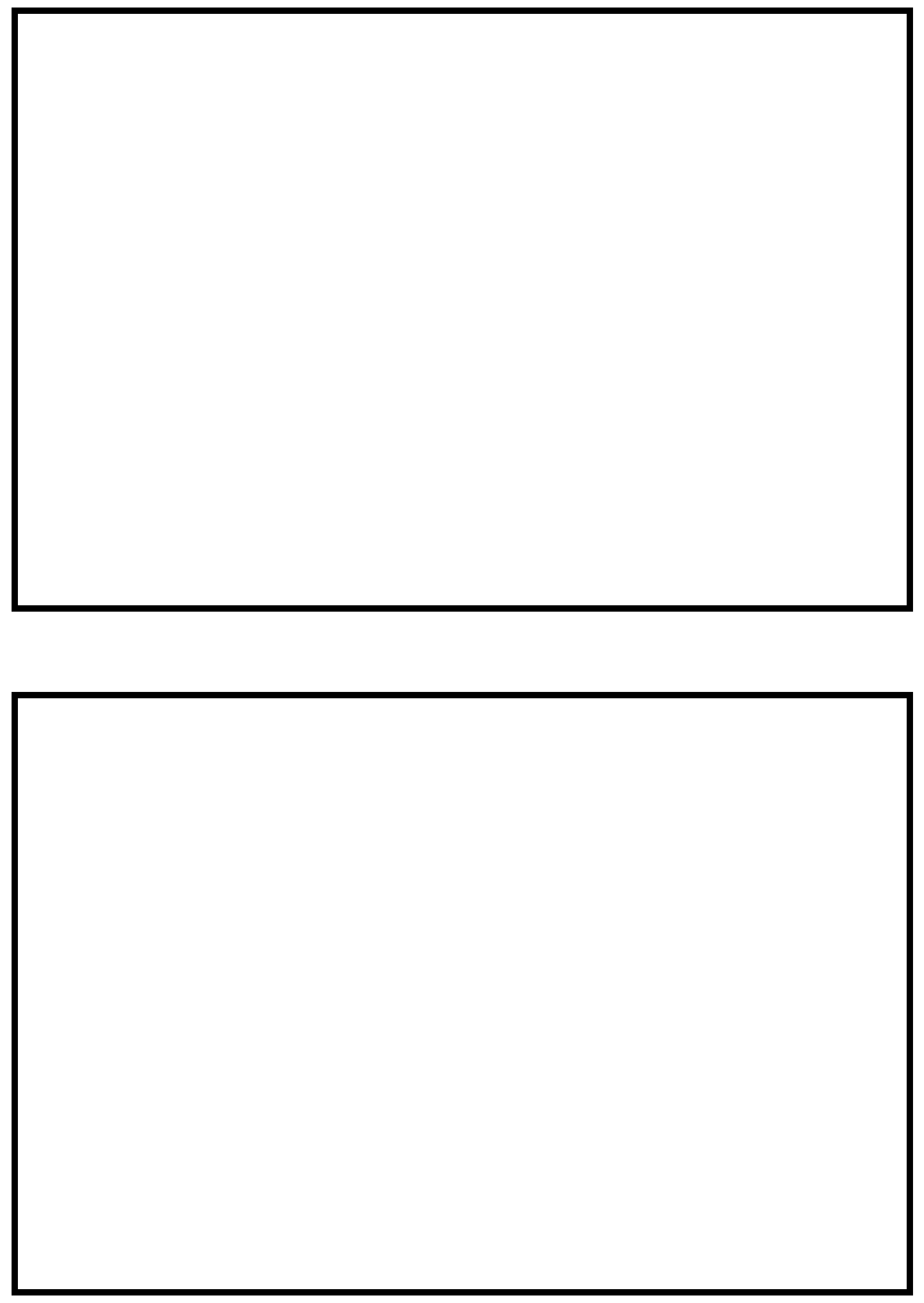

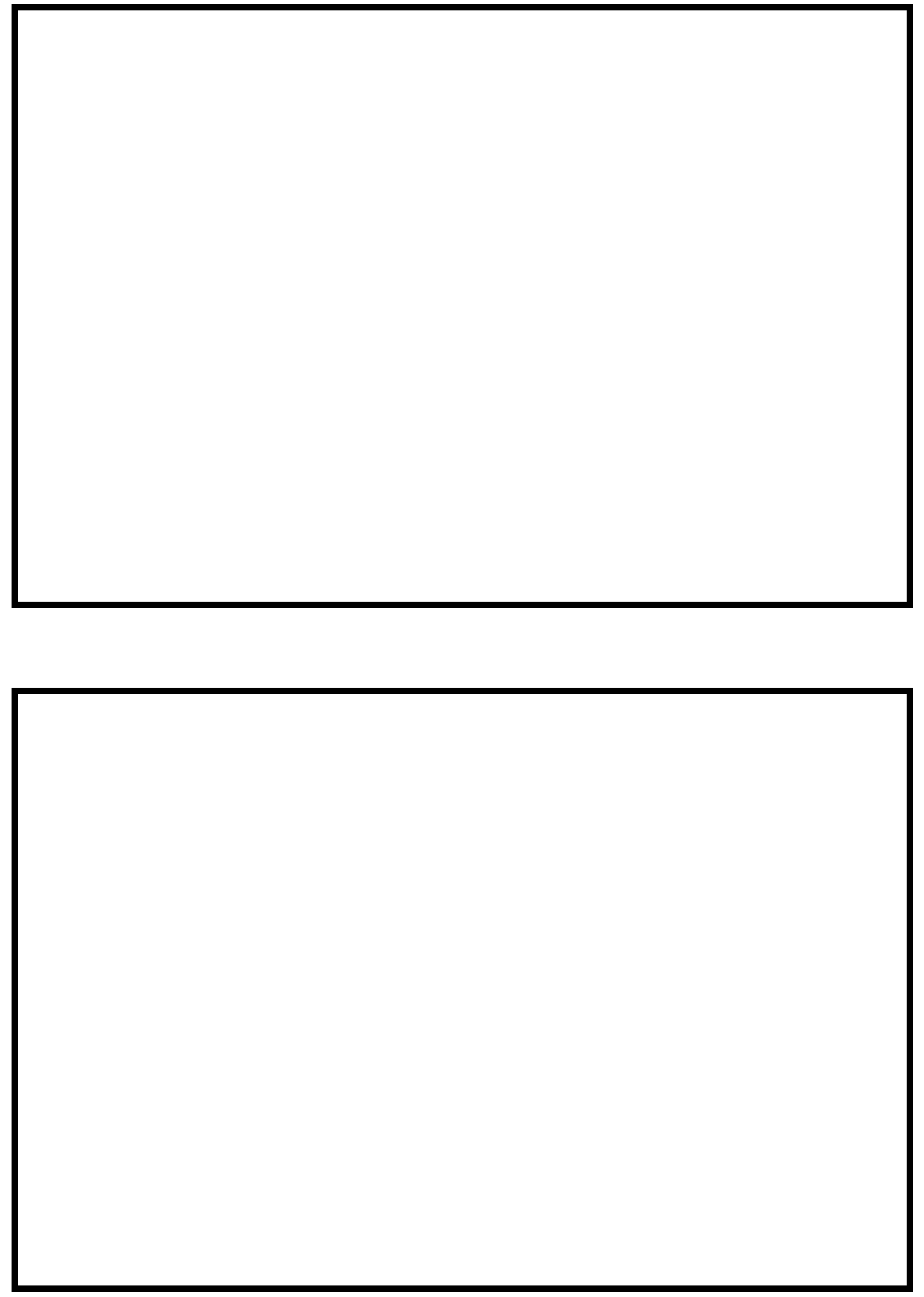


\section{LEVEL II SUMMARY}

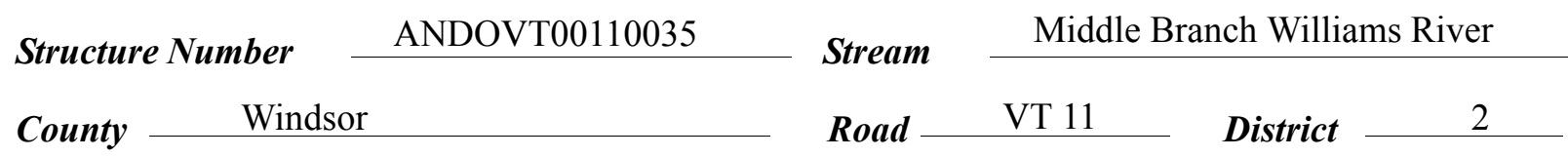

\section{Description of Bridge}

Bridge length $\frac{28}{} \boldsymbol{f t} \quad$ Bridge width $\frac{31.2}{f} \quad$ Max span length $\frac{24}{f t}$ Alignment of bridge to road (on curve or straight)

Abutment type Vertical, concrete

Stone fill on abutment?

$$
\text { No }
$$

\section{Embankment type} Straight

Dato af incnortion Type-1, at the right road approach upstream and downstream. Type-2, deep scour hole in front of the upstream left wingwall and left abutment that deepens to $1.75 \mathrm{ft}$ in front of the downstream left wingwall.

Yes

Angle

45

Is bridge skewed to flood flow according to Yes ' survey?

There is a mild channel bend through the bridge. The scour hole has developed in the location where the flow impacts the left abutment and wingwalls.

Debris accumulation on bridge at time of Level I or Level II site visit:

Date of insnortion $8 / 28 / 96$

Level I

$$
8 / 28 / 96
$$

Level II channel.

Potential for debris

\section{Percent of alommol blocked inorizontatly}

0

\section{Percent of an n....el blocked verticatty}

0

A point bar along the right abutment affects low flow by directing the water towards the left Doscriho anv, fonturos noar ar at tho hridoo that mav, affoct flow, (includo ahsorvation dato) abutment as noted on 8/28/96. 


\section{Description of the Geomorphic Setting}

General topography The channel is located within a moderate relief valley with little or no

flood plains.

Geomorphic conditions at bridge site: downstream (DS), upstream (US)

Date of inspection $\quad 8 / 28 / 96$

DS left: $\quad$ Low channel bank and flat overbank to a steep valley wall

DS right: $\quad$ Low channel bank to a moderately sloped overbank

US left: $\quad$ Steep valley wall

US right: $\quad$ Steep channel bank to a moderately sloped overbank

\section{Description of the Channel}

\begin{tabular}{|c|c|c|c|}
\hline \multirow[b]{2}{*}{ Average top width } & 57 & \multirow[b]{2}{*}{ Average depth } & \multirow[b]{2}{*}{ Sand/Gravel ${ }^{\boldsymbol{f t}}$} \\
\hline & $\stackrel{\boldsymbol{f t}}{\text { Gravel/Cobbles }}$ & & \\
\hline Predominant bed mo & & Bank material & Meandering with \\
\hline
\end{tabular}

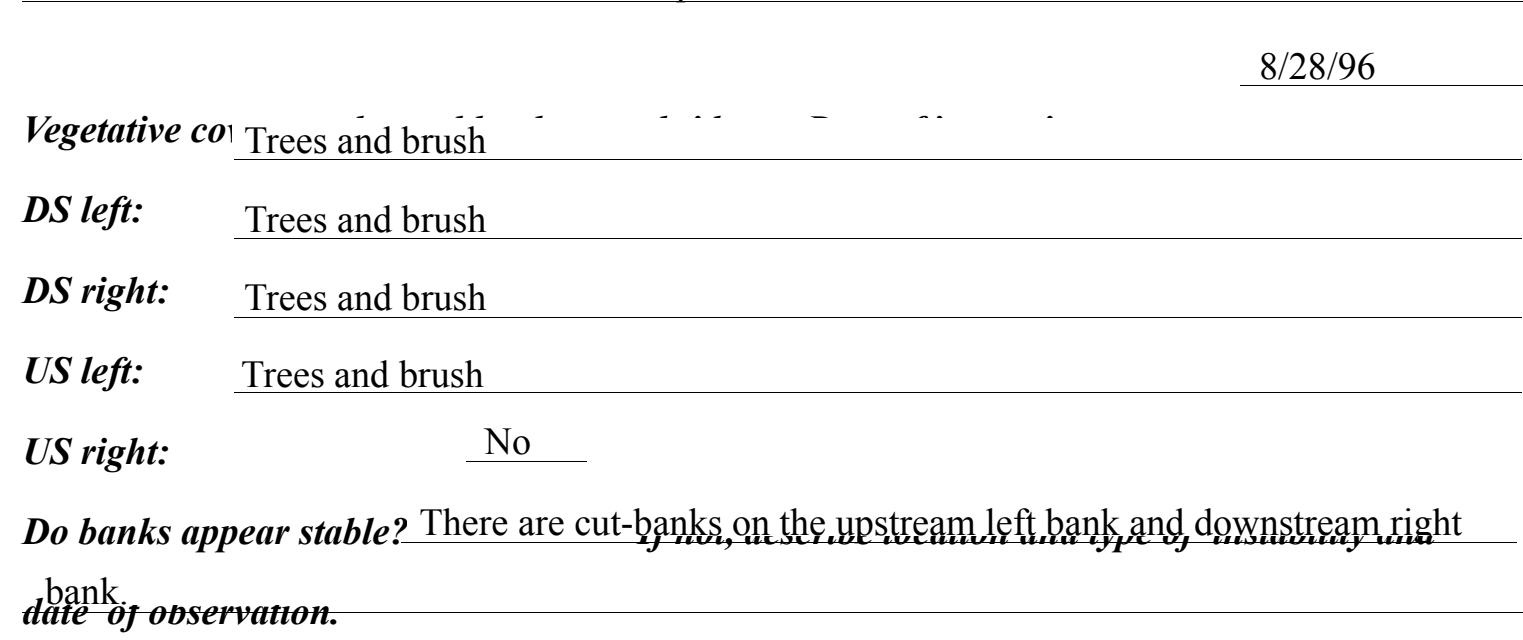

The assessment of $8 / 28 /$

96 noted flow conditions up to bank-full level are influenced by an island in the upstream Describe any obstructions in channel and date of observation.

channel. 


\title{
Hydrology
}

Drainage area $\stackrel{4.65}{\boldsymbol{m i}^{2}}$

Percentage of drainage area in physiographic provinces: (approximate)

Physiographic province/section

New England/Green Mountain
Percent of drainage area 100

\begin{abstract}
Is drainage area considered rural or urban?
Rural None.

urbanization:-
\end{abstract}

Is there a USGS gage on the stream of interest?

No

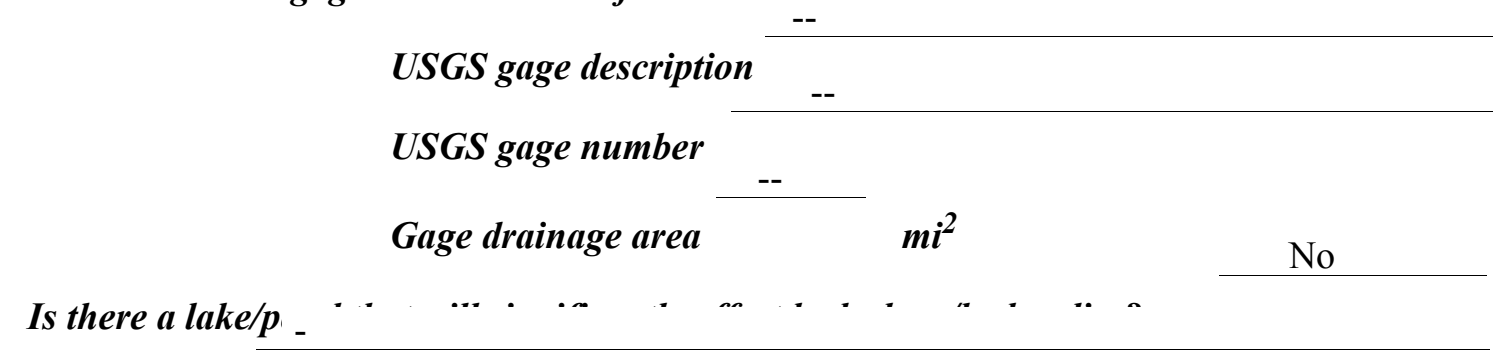

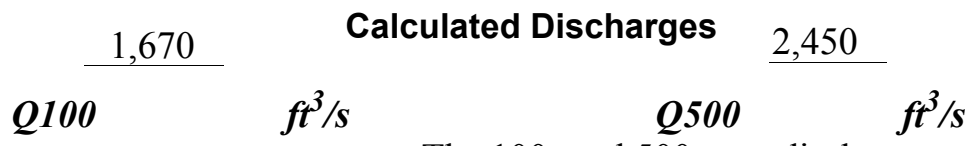

The 100- and 500-year discharges are based on a

drainage area relationship.[(4.65/1.44)exp 0.83] with flood frequency estimates available from the VTAOT database (written communication, May 1995) for bridge number 10 in Windham.

Bridge number 10 crosses the Middle Branch Williams River upstream of this site and has a drainage area of 1.44 square miles. The drainage area adjusted values were within a range defined by flood frequency curves derived from several empirical methods (Benson, 1962; Johnson and Tasker, 1974; FHWA, 1983; Potter, 1957a\&b; Talbot, 1887). 


\section{Description of the Water-Surface Profile Model (WSPRO) Analysis}

Datum for WSPRO analysis (USGS survey, sea level, VTAOT plans)

USGS survey

Datum tie between USGS survey and VTAOT plans

Add 21.3 to the VTAOT plans'

datum to obtain the USGS arbitrary survey datum.

Description of reference marks used to determine USGS datum. $\quad$ RM1 is a chiseled X on top of the downstream end of the left abutment (elev. $518.05 \mathrm{ft}$, arbitrary survey datum). RM2 is a chiseled X on top of the upstream end of the right abutment (elev. $518.28 \mathrm{ft}$, arbitrary survey

datum). RM3 is a survey disk on top of the downstream end of the left abutment of bridge 36,700

ft downstream, (499.25 ft, arbitrary survey datum).

\section{Cross-Sections Used in WSPRO Analysis}

\begin{tabular}{cccl}
\hline ICross-section & $\begin{array}{c}\text { Section } \\
\text { Reference } \\
\text { Distance } \\
\text { (SRD) } \text { in feet }\end{array}$ & $\begin{array}{c}{ }^{2} \text { Cross-section } \\
\text { development }\end{array}$ & \multicolumn{1}{c}{ Comments } \\
\hline EXITX & -30 & 1 & $\begin{array}{l}\text { Exit section } \\
\text { Downstream Full-valley } \\
\text { section (Templated from } \\
\text { EXITX) }\end{array}$ \\
BRIDG & 0 & 2 & $\begin{array}{l}\text { Bridge section } \\
\text { Road Grade section }\end{array}$ \\
RDWAY & 0 & 1 & $\begin{array}{l}\text { Modelled Approach sec- } \\
\text { tion (Templated from } \\
\text { APTEM }\end{array}$ \\
& 14 & 1 & $\begin{array}{l}\text { APTEM) } \\
\text { Approach section as sur- } \\
\text { veyed (Used as a tem- } \\
\text { plate) }\end{array}$ \\
\hline
\end{tabular}

${ }^{1}$ For location of cross-sections see plan-view sketch included with Level I field form, Appendix E. For more detail on how cross-sections were developed see WSPRO input file. 


\section{Data and Assumptions Used in WSPRO Model}

Hydraulic analyses of the reach were done by use of the Federal Highway Administration's WSPRO step-backwater computer program (Shearman and others, 1986, and Shearman, 1990). The analyses reported herein reflect conditions existing at the site at the time of the study. Furthermore, in the development of the model it was necessary to assume no accumulation of debris or ice at the site. Results of the hydraulic model are presented in the Bridge Hydraulic Summary, appendix B, and figure 7.

Channel roughness factors (Manning's " $n$ ") used in the hydraulic model were estimated using field inspections at each cross section following the general guidelines described by Arcement and Schneider (1989). Final adjustments to the values were made during the modelling of the reach. Channel " $\mathrm{n}$ " values for the reach ranged from 0.040 to 0.063 , and overbank " $n$ " values ranged from 0.060 to 0.070 .

Normal depth at the exit section (EXITX) was assumed as the starting water surface. This depth was computed by use of the slope-conveyance method outlined in the user's manual for WSPRO (Shearman, 1990). The slope used was $0.0161 \mathrm{ft} / \mathrm{ft}$, which was estimated from surveyed thalweg points downstream of the bridge.

The surveyed approach section (APTEM) was moved along the approach channel slope $(0.0317 \mathrm{ft} / \mathrm{ft})$ to establish the modelled approach section (APPRO), one bridge length upstream of the upstream face as recommended by Shearman and others (1986). This location provides a consistent method for determining scour variables.

For the incipient-overtopping discharge, WSPRO assumes critical depth at the bridge section. A supercritical model was developed for this discharge. After analyzing both the supercritical and subcritical profiles, it was determined that the water surface profile does pass through critical depth within the bridge opening. Thus, the assumption of critical depth at the bridge is a satisfactory solution. 


\section{Bridge Hydraulics Summary}

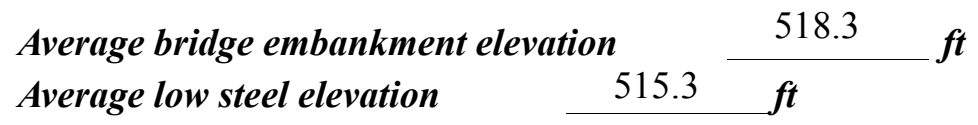

\begin{tabular}{|c|c|c|c|c|}
\hline \multirow{2}{*}{\multicolumn{3}{|c|}{$\begin{array}{l}\text { 100-year discharge } \\
\text { Water-surface elevation in bridge opening }\end{array}$}} & \multirow[b]{2}{*}{515.5} & \multirow[b]{2}{*}{$f t$} \\
\hline & & & & \\
\hline Road overtopping? & Yes & \multicolumn{2}{|c|}{ Discharge over road } & \multirow[t]{2}{*}{22} \\
\hline \multicolumn{2}{|c|}{ Area of flow in bridge opening } & \multicolumn{2}{|c|}{$f t^{2}$} & \\
\hline Average velocity in $b$ & e openin & 8.7 & $f t / s$ & \\
\hline Maximum WSPRO & elocity & at hrido & 11.4 & $f t / s$ \\
\hline
\end{tabular}

Water-surface elevation at Approach section with bridge Water-surface elevation at Approach section without bridge

517.1

Amount of backwater caused by bridge
$6.0 \quad$ it

500-year discharge $\quad 2,450 \quad \mathrm{ft}^{3} / \mathrm{s}$

Water-surface elevation in bridge opening $515.5 f t$

Road overtopping? ___ Yes Discharge over road

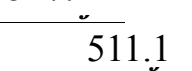

Area of flow in bridge opening 192

Average velocity in bridge opening $\mathrm{ft}^{2}$

Maximum WSPRO tube velocity at bridge $10.5 \mathrm{ft} / \mathrm{s}$

$13.8, / s$

Water-surface elevation at Approach section with bridge

Water-surface elevation at Approach section without bridge

518.4

Amount of backwater caused by bridge $456,-3$

Incipient overtopping discharge $\quad 1,500 \mathrm{ft}^{3} / \mathrm{s}$

Water-surface elevation in bridge opening $\quad 511.7 \quad t$

Area of flow in bridge opening

Average velocity in bridge opening

$114 \mathrm{ft}^{2}$

Maximum WSPRO tube velocity at bridge

$13.1 \mathrm{ft} / \mathrm{s}$

$17.9 \mathrm{ft} / \mathrm{s}$

Water-surface elevation at Approach section with bridge

Water-surface elevation at Approach section without bridge

515.4

Amount of backwater caused by bridge 4.4 . $t$ 


\section{Scour Analysis Summary}

\section{Special Conditions or Assumptions Made in Scour Analysis}

Scour depths were computed using the general guidelines described in Hydraulic Engineering Circular 18 (Richardson and Davis, 1995). Scour depths were calculated assuming an infinite depth of erosive material and a homogeneous particle-size distribution. The results of the scour analyses for the 100- and 500-year discharges are presented in tables 1 and 2 and the scour depths are shown graphically in figure 8 .

Contraction scour for the incipient roadway-overtopping discharge was computed by use of the Laursen clear-water contraction scour equation (Richardson and Davis, 1995, p. 32 , equation 20). At this site, the 100- and 500-year discharges resulted in unsubmerged orifice flow. Contraction scour at bridges with orifice flow is best estimated by use of the Chang pressure-flow scour equation (oral communication, J. Sterling Jones, October 4, 1996). Thus, contraction scour for these discharges was computed by use of the Chang equation (Richardson and Davis, 1995, p. 145-146).

For comparison, contraction scour for the discharges resulting in orifice flow was also computed by use of the Laursen clear-water contraction scour equation and the Umbrell pressure-flow equation (Richardson and Davis, 1995, p. 144) and is presented in appendix F. Furthermore, for those discharges resulting in unsubmerged orifice flow, contraction scour was computed by substituting estimates for the depth of flow at the downstream bridge face in the contraction scour equations. Results with respect to these substitutions are provided in appendix $\mathrm{F}$.

Abutment scour was computed for all modeled flows by use of the Froehlich equation (Richardson and Davis, 1995, p. 48, equation 28). Variables for the Froehlich equation include the Froude number of the flow approaching the embankments, the length of the embankment blocking flow, and the depth of flow approaching the embankment less any roadway overtopping.

The length to depth ratio of the embankment blocking flow exceeded 25 for the 100and 500-year discharges at both abutments and for the incipient road-overtopping discharge at the left abutment. Although the HIRE equation (Richardson and Davis, 1993, p. 50, equation 25) is generally applicable when this ratio exceeds 25 , the results from the HIRE equation were not used. Hydraulic Engineering Circular 18 recommends that the field conditions be similar to those from which the HIRE equation was derived (Richardson and Davis, 1993). Since the equation was developed from Army Corp of Engineers' data obtained for spur dikes in the Mississippi River, the HIRE equation was not adopted for the narrow, incised, upland valley at this site. 


\section{Scour Results}

$$
\text { 100-yr discharge 500-yr discharge }
$$

Contraction scour:

(Scour depths in feet)

Main channel

Live-bed scour

Clear-water scour

Depth to armoring

Left overbank

Right overbank

Local scour:

Abutment scour

Left abutment

Right abutment

Pier scour

Pier 1

Pier 2

Pier 3
15.3

6.3-
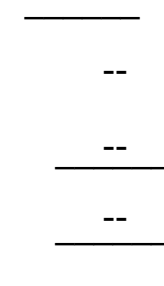

16.5

$8.8-$
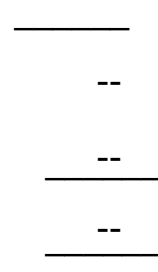

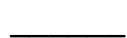

14.4

7.9-

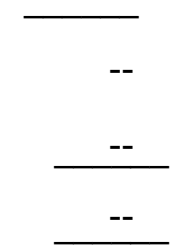

\section{Riprap Sizing}

Abutments:

\section{Left abutment}

Right abutment

Piers:

Pier 1

Pier 2

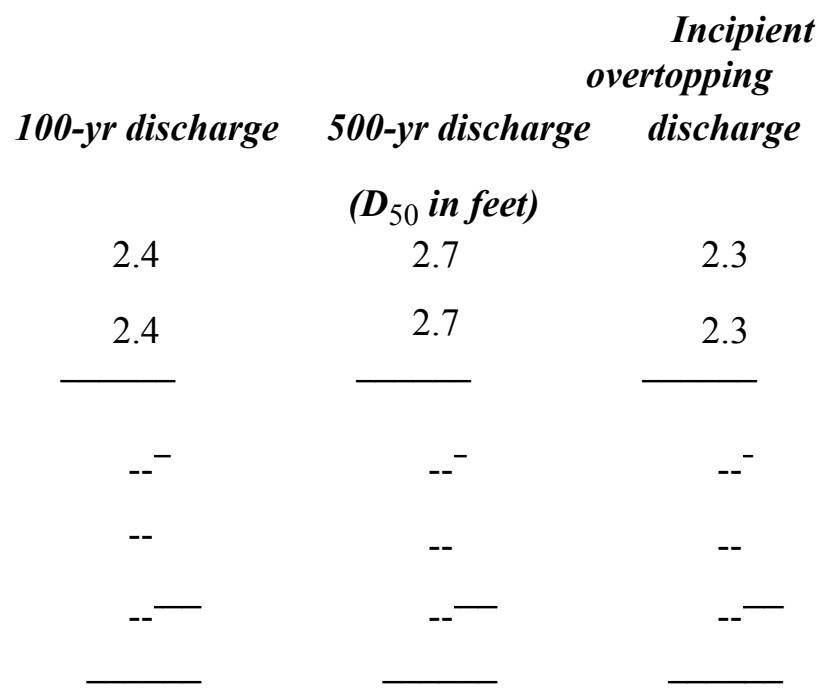




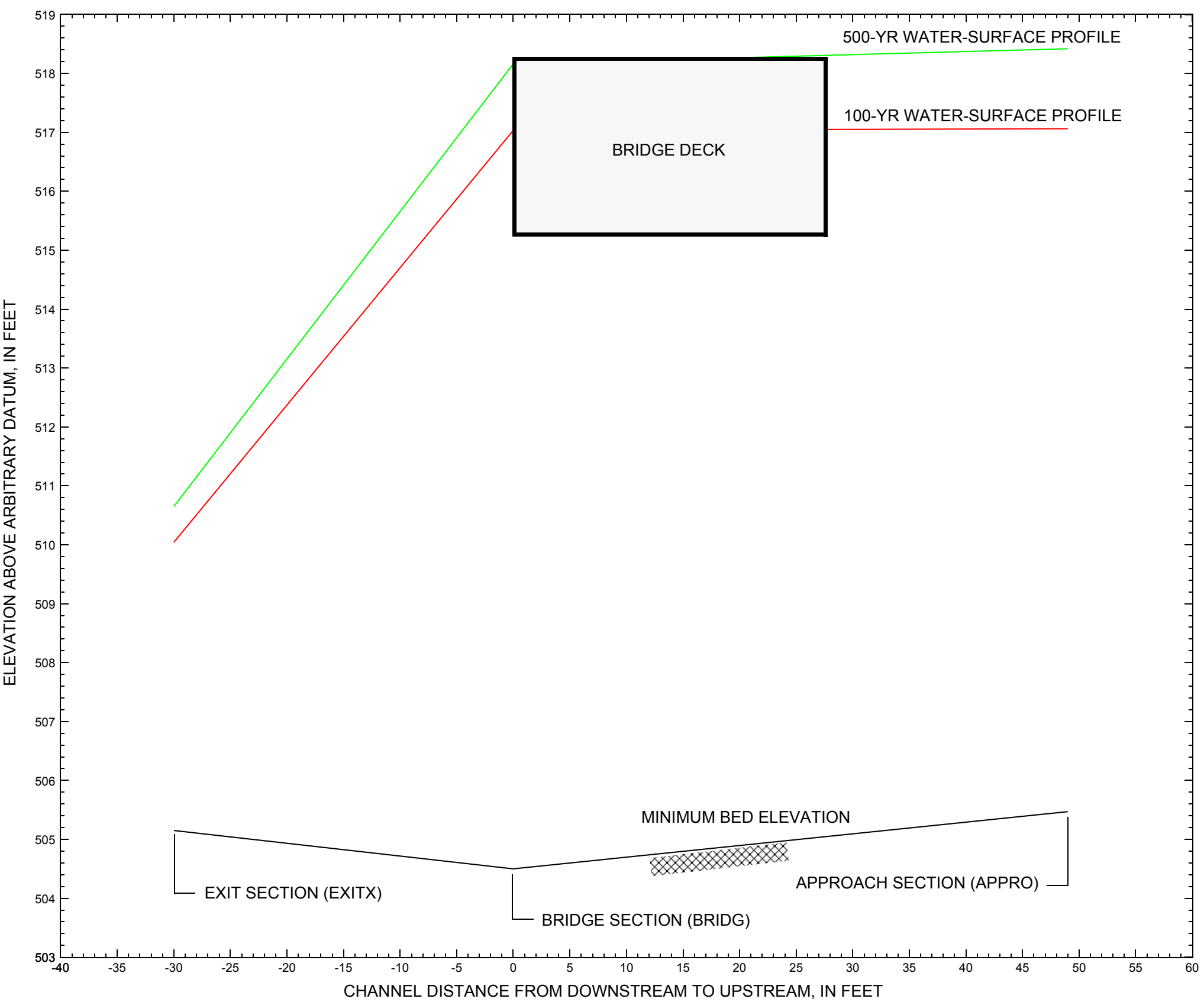

Figure 7. Water-surface profiles for the 100- and 500-yr discharges at structure ANDOVT00110035 on State Route 11, crossing the Middle Branch Williams River, Andover, Vermont. 


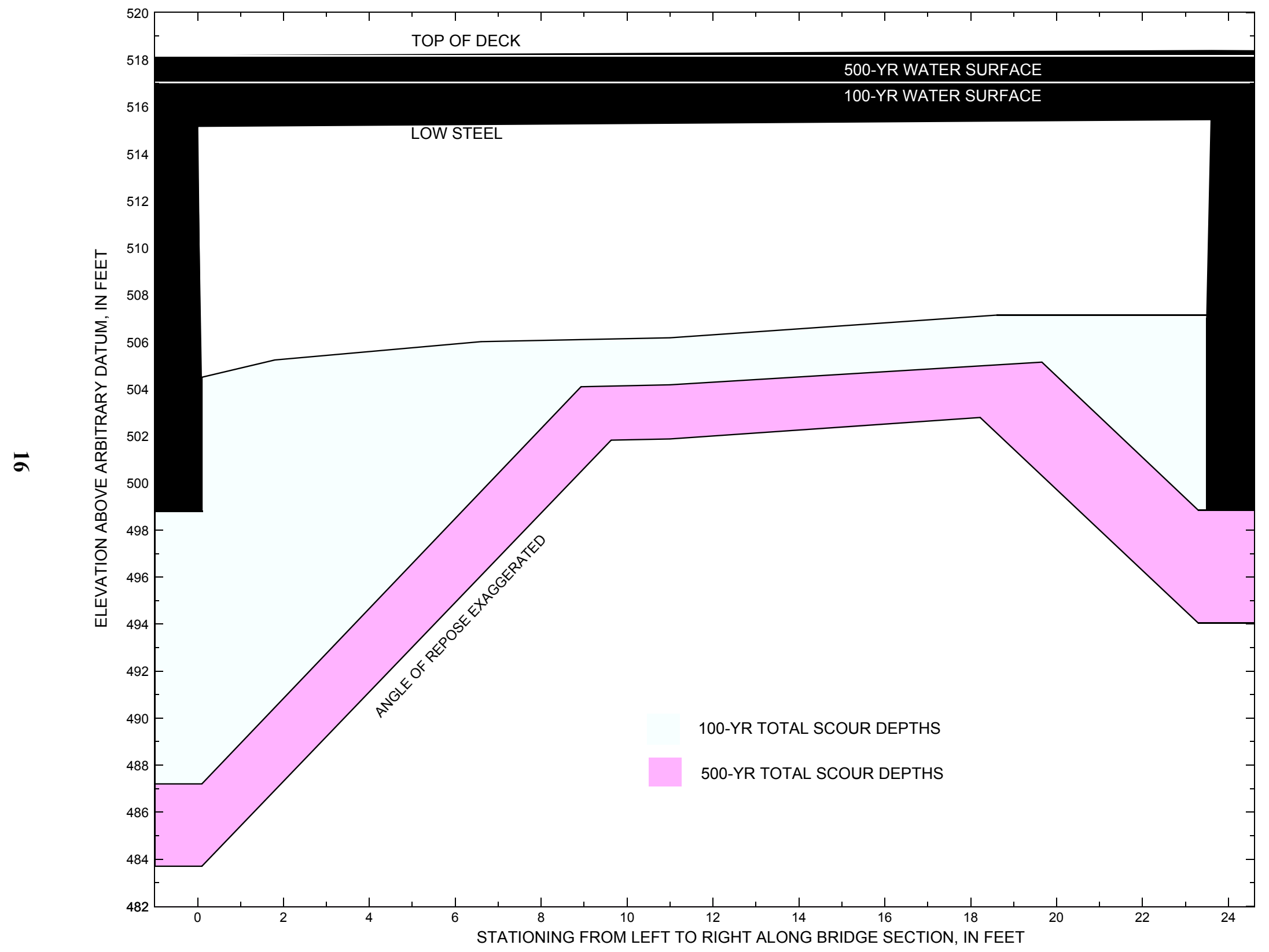

Figure 8. Scour elevations for the 100- and 500-yr discharges at structure ANDOVT00110035 on State Route 11, crossing the Middle Branch Williams River, Andover, Vermont. 
Table 1. Remaining footing/pile depth at abutments for the 100-yr discharge at structure ANDOVT00110035 on State Route 11, crossing the Middle Branch Williams River, Andover, Vermont.

[VTAOT, Vermont Agency of Transportation; --, no data]

\begin{tabular}{|c|c|c|c|c|c|c|c|c|c|c|c|}
\hline Description & Station $^{1}$ & $\begin{array}{l}\text { VTAOT } \\
\text { minimum } \\
\text { bridge seat } \\
\text { elevation } \\
\text { (feet) }\end{array}$ & $\begin{array}{l}\text { Surveyed } \\
\text { minimum } \\
\text { low-chord } \\
\text { elevation } \\
\quad \text { (feet) }\end{array}$ & $\begin{array}{c}\text { Bottom of } \\
\text { footing/pile } \\
\text { elevation }^{2} \\
\text { (feet) }\end{array}$ & $\begin{array}{c}\text { Channel } \\
\text { elevation at } \\
\text { abutment/ } \\
\text { pier }^{2} \\
\text { (feet) }\end{array}$ & $\begin{array}{l}\text { Contraction } \\
\text { scour depth } \\
\text { (feet) }\end{array}$ & $\begin{array}{l}\text { Abutment } \\
\text { scour } \\
\text { depth } \\
\text { (feet) }\end{array}$ & $\begin{array}{l}\text { Pier } \\
\text { scour } \\
\text { depth } \\
\text { (feet) }\end{array}$ & $\begin{array}{l}\text { Depth of } \\
\text { total scour } \\
\text { (feet) }\end{array}$ & $\begin{array}{c}\text { Elevation of } \\
\text { scour }^{2} \\
\text { (feet) }\end{array}$ & $\begin{array}{l}\text { Remaining } \\
\text { footing/pile } \\
\text { depth } \\
\text { (feet) }\end{array}$ \\
\hline \multicolumn{12}{|c|}{100 -yr discharge is 1,670 cubic-feet per second } \\
\hline Left abutment & 0.0 & 494.0 & 515.2 & 498.8 & 504.5 & 2.0 & 15.3 & -- & 17.3 & 487.2 & -11.6 \\
\hline Right abutment & 23.6 & 494.0 & 515.5 & 498.8 & 507.0 & 2.0 & 6.3 & -- & 8.3 & 498.7 & -0.1 \\
\hline
\end{tabular}

1.Measured along the face of the most constricting side of the bridge.

2.Arbitrary datum for this study.

Table 2. Remaining footing/pile depth at abutments for the 500-yr discharge at structure ANDOVT00110035 on State Route 11, crossing the Middle Branch Williams River, Andover, Vermont.

[VTAOT, Vermont Agency of Transportation; --, no data]

\begin{tabular}{|c|c|c|c|c|c|c|c|c|c|c|c|}
\hline Description & Station ${ }^{1}$ & $\begin{array}{l}\text { VTAOT } \\
\text { minimum } \\
\text { bridge seat } \\
\text { elevation } \\
\text { (feet) }\end{array}$ & $\begin{array}{c}\text { Surveyed } \\
\text { minimum } \\
\text { low-chord } \\
\text { elevation }{ }^{2} \\
\text { (feet) }\end{array}$ & $\begin{array}{c}\text { Bottom of } \\
\text { footing/pile } \\
\text { elevation }{ }^{2} \\
\text { (feet) }\end{array}$ & $\begin{array}{c}\text { Channel } \\
\text { elevation at } \\
\text { abutment/ } \\
\text { pier }^{2} \\
\text { (feet) }\end{array}$ & $\begin{array}{l}\text { Contraction } \\
\text { scour depth } \\
\text { (feet) }\end{array}$ & $\begin{array}{l}\text { Abutment } \\
\text { scour } \\
\text { depth } \\
\text { (feet) }\end{array}$ & $\begin{array}{l}\text { Pier } \\
\text { scour } \\
\text { depth } \\
\text { (feet) }\end{array}$ & $\begin{array}{l}\text { Depth of } \\
\text { total scour } \\
\text { (feet) }\end{array}$ & $\begin{array}{c}\text { Elevation of } \\
\text { scour }^{2} \\
\text { (feet) }\end{array}$ & $\begin{array}{c}\text { Remaining } \\
\text { footing/pile } \\
\text { depth } \\
\text { (feet) }\end{array}$ \\
\hline \multicolumn{12}{|c|}{500 -yr discharge is 2,450 cubic-feet per second } \\
\hline Left abutment & 0.0 & 494.0 & 515.2 & 498.8 & 504.5 & 4.3 & 16.5 & -- & 20.8 & 483.7 & -15.1 \\
\hline Right abutment & 23.6 & 494.0 & 515.5 & 498.8 & 507.0 & 4.3 & 8.8 & -- & 13.1 & 493.9 & -4.9 \\
\hline
\end{tabular}

1.Measured along the face of the most constricting side of the bridge.

2.Arbitrary datum for this study. 


\section{SELECTED REFERENCES}

Arcement, G.J., Jr., and Schneider, V.R., 1989, Guide for selecting Manning's roughness coefficients for natural channels and flood plains:

U.S. Geological Survey Water-Supply Paper 2339, 38 p.

Barnes, H.H., Jr., 1967, Roughness characteristics of natural channels: U.S. Geological Survey Water-Supply Paper 1849,213 p.

Benson, M. A., 1962, Factors Influencing the Occurrence of Floods in a Humid Region of Diverse Terrain: U.S. Geological Survey WaterSupply Paper 1580-B, 64 p.

Brown, S.A. and Clyde, E.S., 1989, Design of riprap revetment: Federal Highway Administration Hydraulic Engineering Circular No. 11, Publication FHWA-IP-89-016, 156 p.

Federal Emergency Management Agency, 1982, Flood Insurance Study, Town of Chester, Windsor County, Vermont: Washington, D.C., February 1982.

Federal Highway Administration, 1983, Runoff estimates for small watersheds and development of sound design: Federal Highway Administration Report FHWA-RD-77-158.

Federal Highway Administration, 1993, Stream Stability and Scour at Highway Bridges: Participant Workbook: Federal Highway Administration Report FHWA-HI-91-011.

Froehlich, D.C., 1989, Local scour at bridge abutments in Ports, M.A., ed., Hydraulic Engineering--Proceedings of the 1989 National Conference on Hydraulic Engineering: New York, American Society of Civil Engineers, p. 13-18.

Hayes, D.C.,1993, Site selection and collection of bridge-scour data in Delaware, Maryland, and Virginia: U.S. Geological Survey WaterResources Investigation Report 93-4017, 23 p.

Interagency Advisory Committee on Water Data, 1982, Guidelines for determining flood flow frequency: U.S. Geological Survey, Bulletin 17B of the Hydrology Subcommittee, 190 p.

Johnson, C.G. and Tasker, G.D.,1974, Progress report on flood magnitude and frequency of Vermont streams: U.S. Geological Survey OpenFile Report 74-130, 37 p.

Lagasse, P.F., Schall, J.D., Johnson, F., Richardson, E.V., Chang, F., 1995, Stream Stability at Highway Structures: Federal Highway Administration Hydraulic Engineering Circular No. 20, Publication FHWA-IP-90-014, 144 p.

Laursen, E.M., 1960, Scour at bridge crossings: Journal of the Hydraulics Division, American Society of Civil Engineers, v. 86, no. HY2, p. 39-53.

Potter, W. D., 1957a, Peak rates of runoff in the Adirondack, White Mountains, and Maine woods area, Bureau of Public Roads

Potter, W. D., 1957b, Peak rates of runoff in the New England Hill and Lowland area, Bureau of Public Roads

Richardson, E.V. and Davis, S.R., 1995, Evaluating scour at bridges: Federal Highway Administration Hydraulic Engineering Circular No. 18, Publication FHWA-IP-90-017, 204 p.

Richardson, E.V., Simons, D.B., and Julien, P.Y., 1990, Highways in the river environment: Federal Highway Administration Publication FHWA-HI-90-016.

Ritter, D.F., 1984, Process Geomorphology: W.C. Brown Co., Debuque, Iowa, 603 p.

Shearman, J.O., 1990, User's manual for WSPRO--a computer model for water surface profile computations: Federal Highway Administration Publication FHWA-IP-89-027, 187 p.

Shearman, J.O., Kirby, W.H., Schneider, V.R., and Flippo, H.N., 1986, Bridge waterways analysis model; research report: Federal Highway Administration Publication FHWA-RD-86-108, 112 p.

Talbot, A.N., 1887, The determination of water-way for bridges and culverts.

U.S. Geological Survey, 1984, Saxtons River, Vermont 7.5 x 15 Minute Series quadrangle map: U.S. Geological Survey Topographic Maps, Scale 1:25,000. 


\section{APPENDIX A: \\ WSPRO INPUT FILE}




\section{WSPRO INPUT FILE}

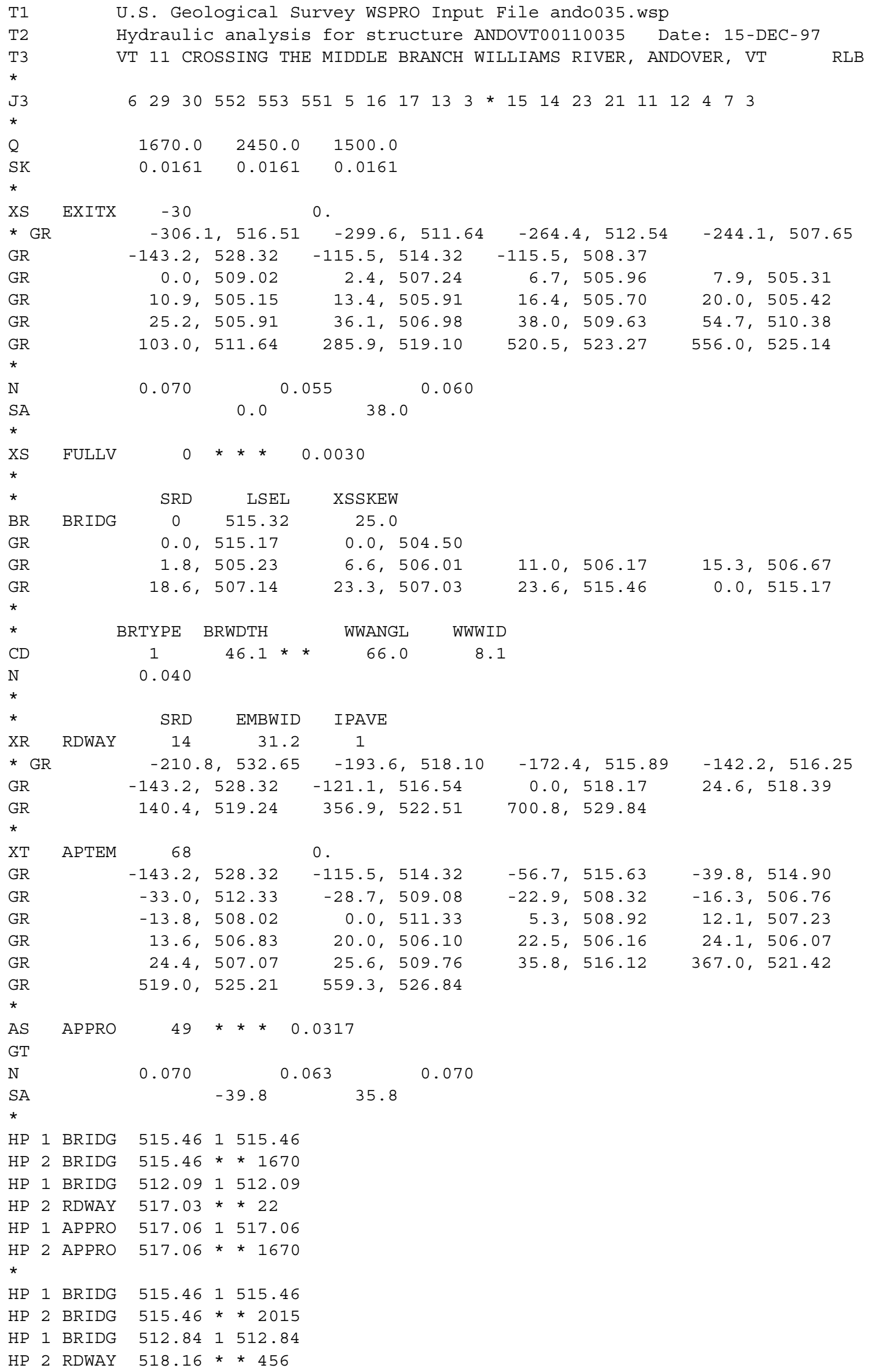




\section{APPENDIX B: \\ WSPRO OUTPUT FILE}




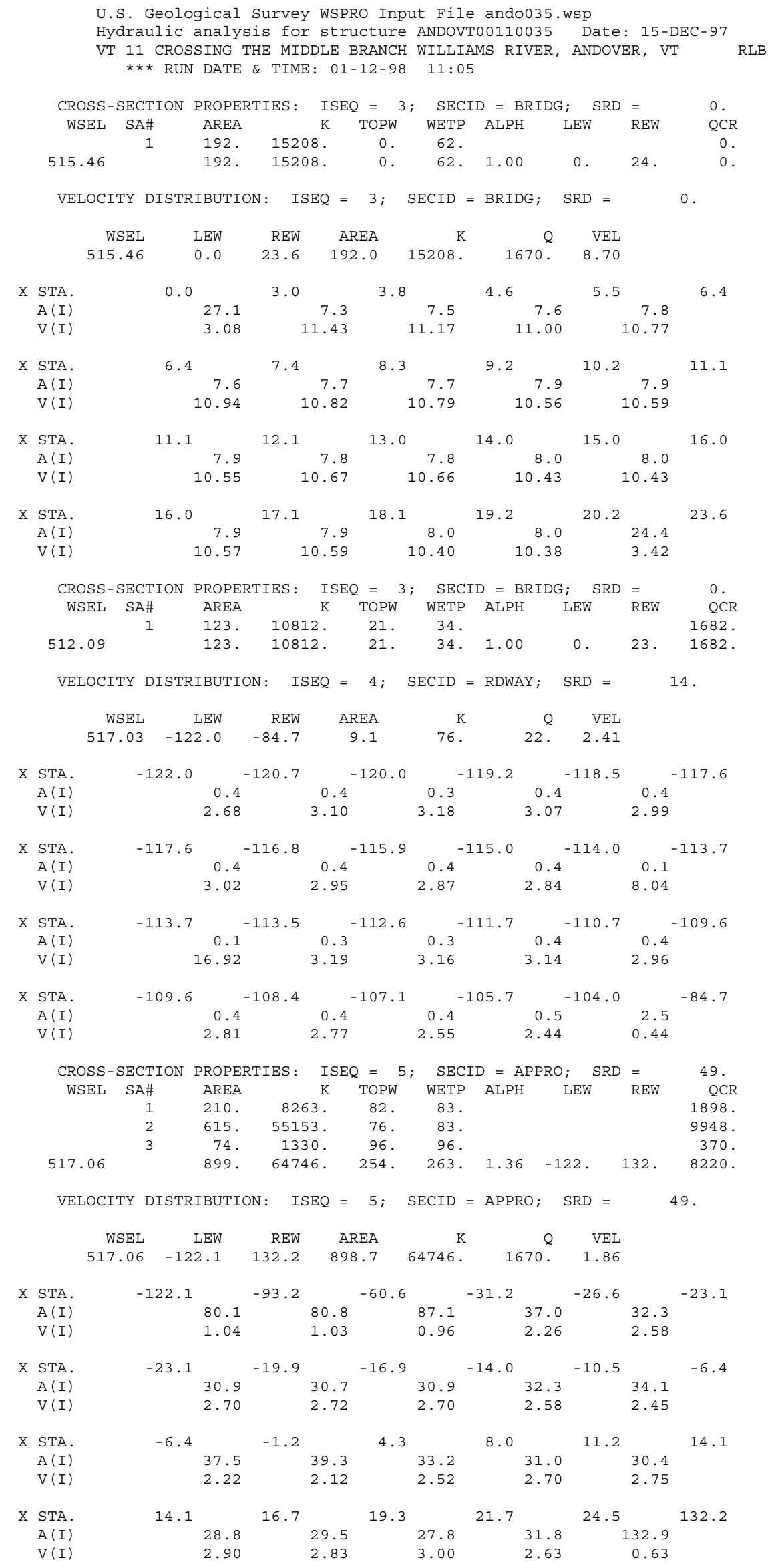




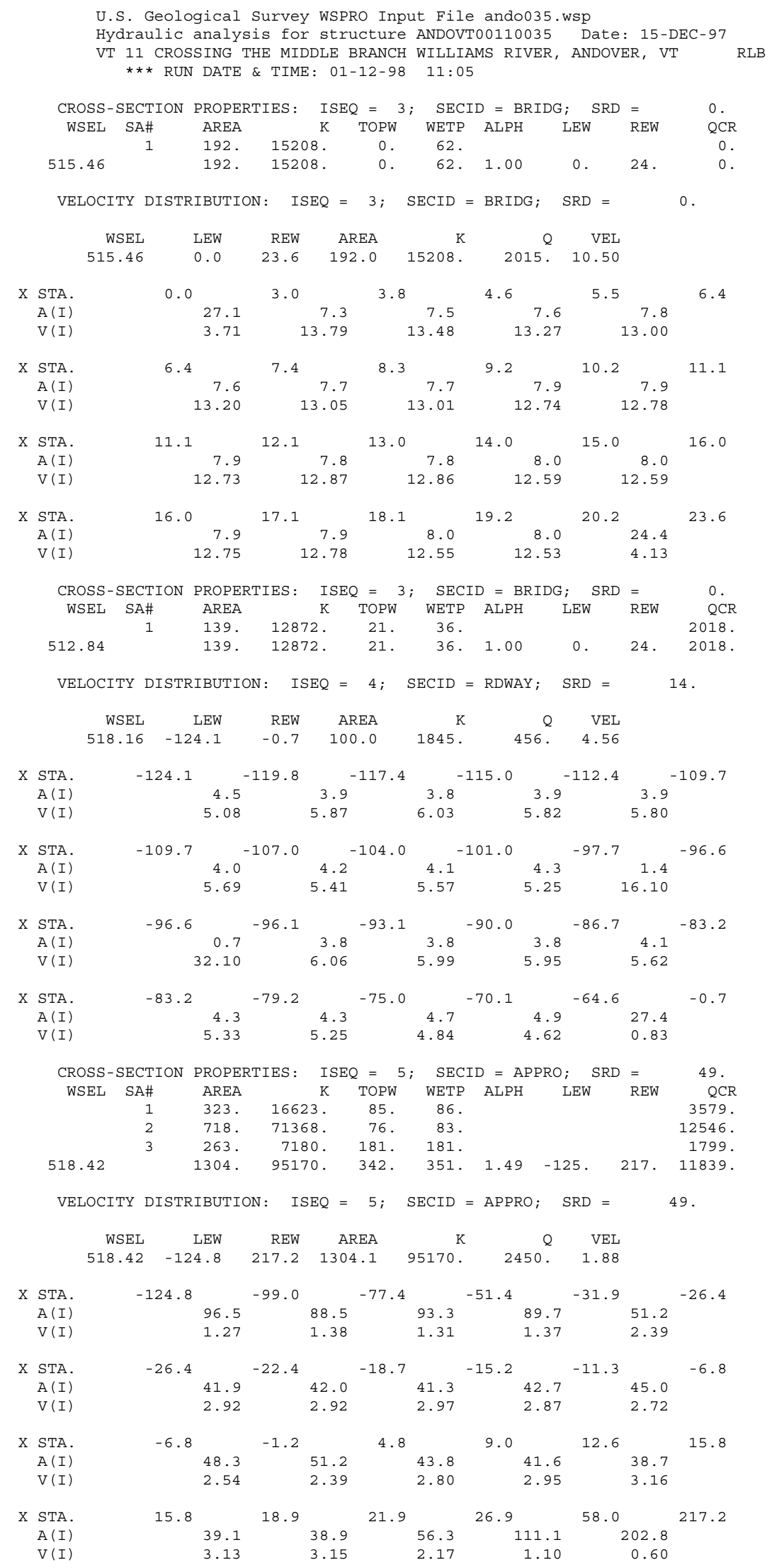


WSPRO OUTPUT FILE (continued)

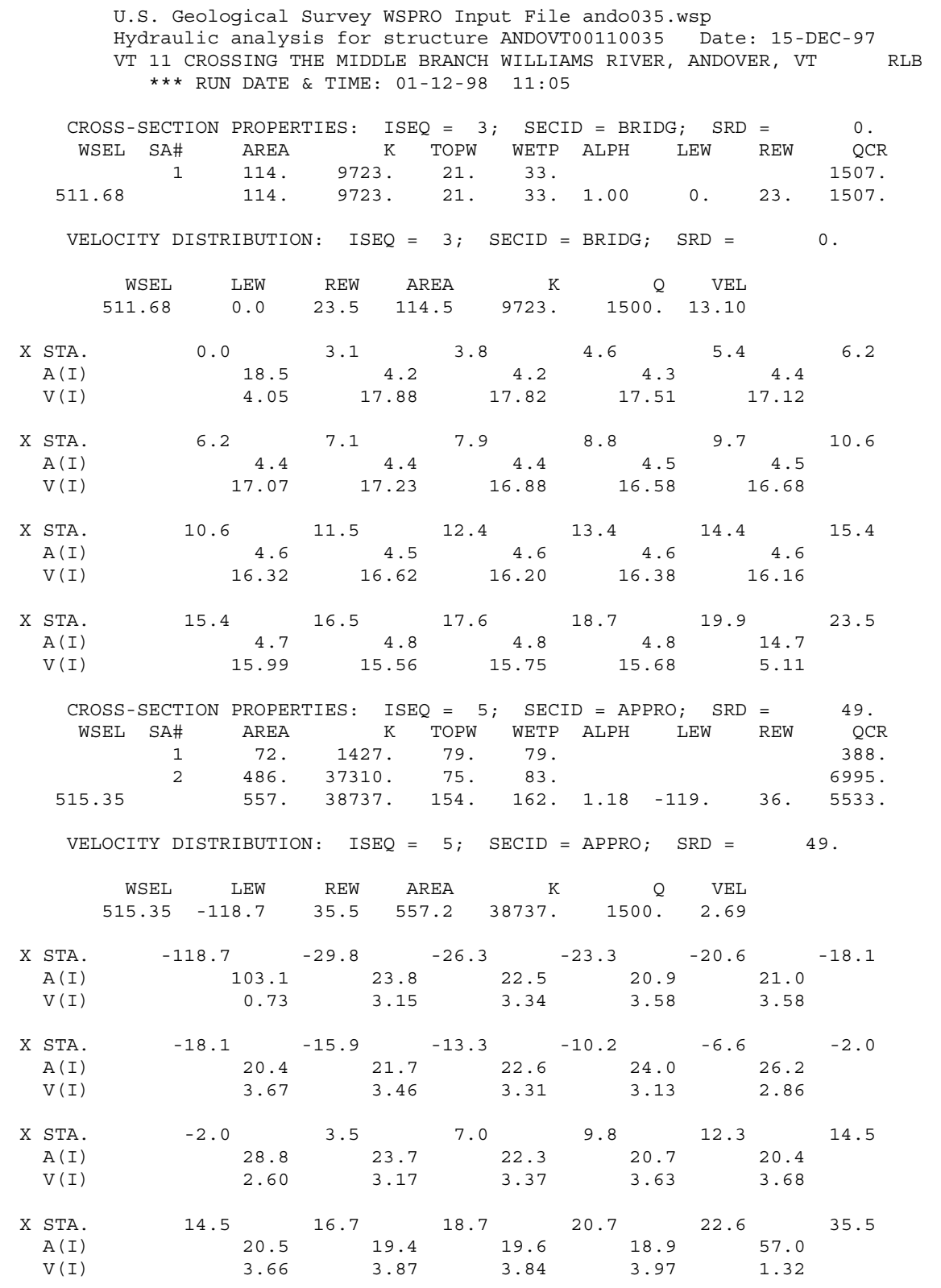


WSPRO OUTPUT FILE (continued)

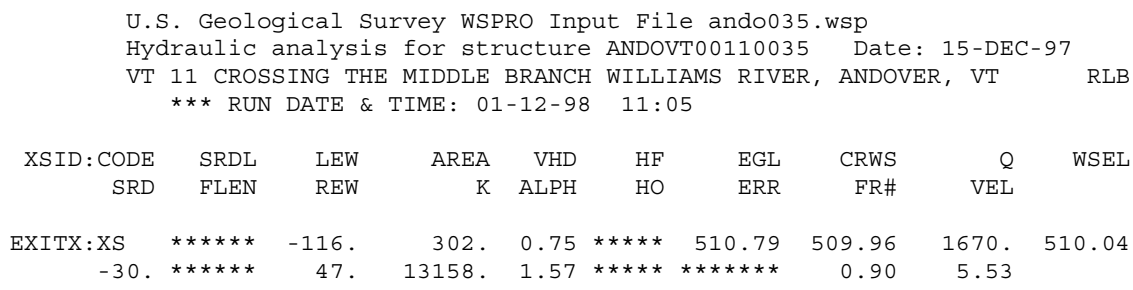

$===135$ CONVEYANCE RATIO OUTSIDE OF RECOMMENDED LIMITS

"FULLV" KRATIO $=1.43$

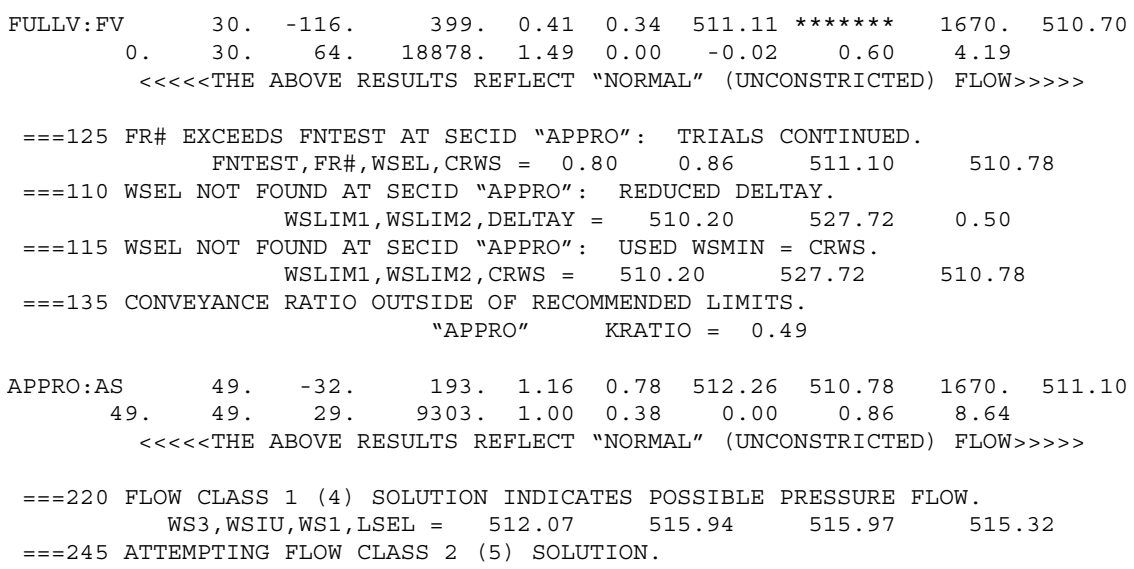


WSPRO OUTPUT FILE (continued)

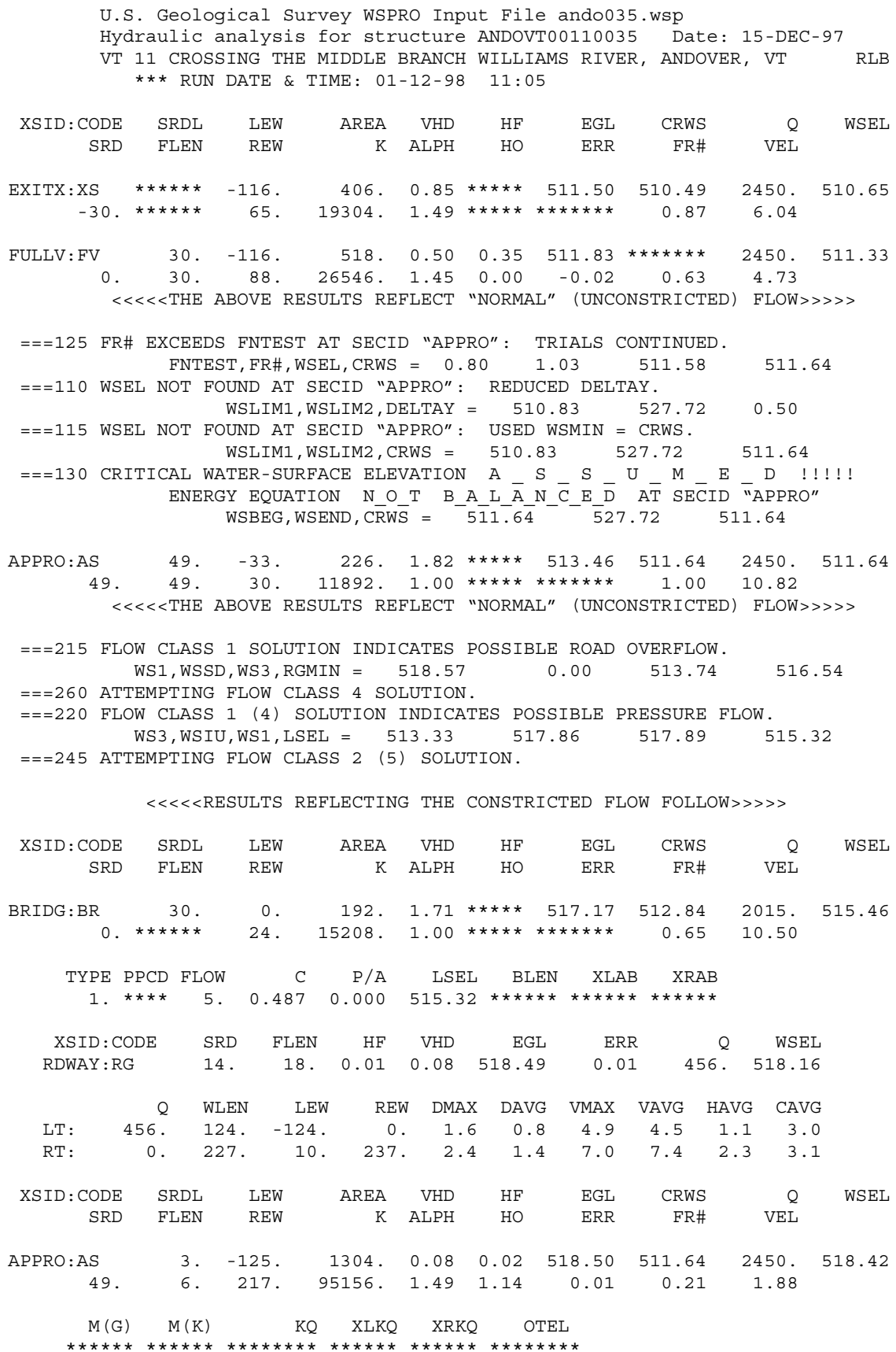

SECOND USER DEFINED TABLE.

\begin{tabular}{|c|c|c|c|c|c|c|c|c|c|}
\hline $\mathrm{E}$ & CRWS & FR\# & YMIN & YMAX & $\mathrm{HF}$ & $\mathrm{HO}$ & VHD & EGL & \\
\hline EXITX:XS & 510.49 & .87 & 05.15 & $28.32 *$ & & & 0.85 & 11.50 & 10 \\
\hline UL & 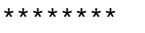 & 3 & 5.24 & 28.41 & 0.35 & 0.00 & .50 & 1.83 & \\
\hline R & 2.84 & J & & 15. & $* \star \star \star * *$ & $* \star \star * *$ & 71 & .17 & \\
\hline & 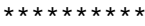 & $\approx *$ & & 9.84 & 0 & $* \star * \star * *$ & 8 & 49 & \\
\hline PPRO : AS & 511.64 & 0.21 & 505.47 & 527.72 & 0.02 & 1.14 & 0.08 & 518.50 & 18 \\
\hline
\end{tabular}


WSPRO OUTPUT FILE (continued)

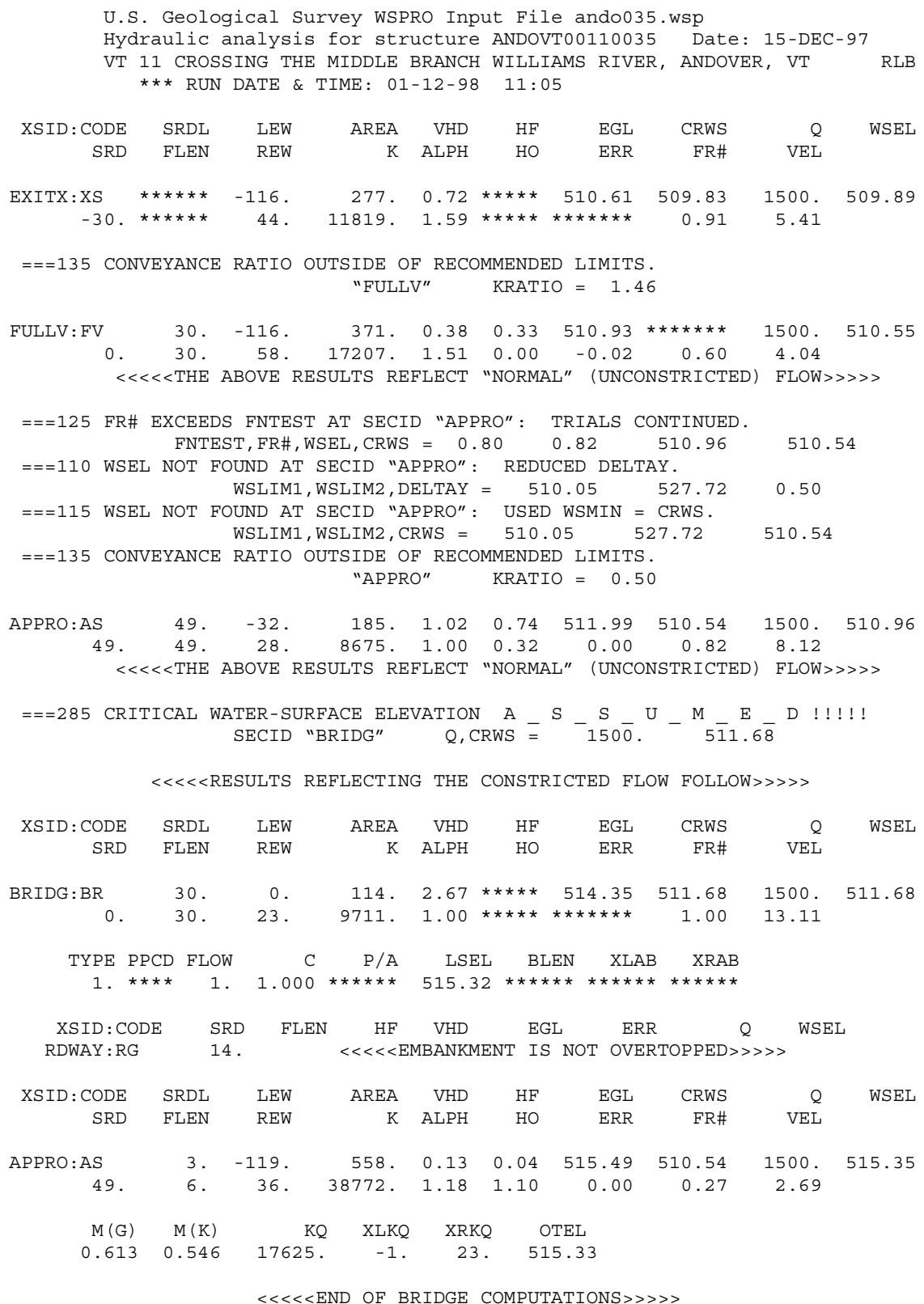

FIRST USER DEFINED TABLE.

\begin{tabular}{|c|c|c|c|c|c|c|c|c|}
\hline XSID: CODE & SRD & LEW & REW & $Q$ & $\mathrm{~K}$ & AREA & VEL & WSEL \\
\hline EXITX : XS & -30 . & -116. & 44 . & 1500. & 11819. & 277. & 5.41 & 509.89 \\
\hline FULLV : FV & 0 . & -116. & 58. & 1500. & 17207. & 371. & 4.04 & 510.55 \\
\hline BRIDG : BR & 0. & 0 . & 23. & 1500. & 9711. & 114. & 13.11 & 511.68 \\
\hline RDWAY : RG & \multicolumn{3}{|c|}{$14 . * * \star * \star * \star * * * * \star * * *$} & \multicolumn{3}{|c|}{ 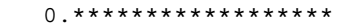 } & \multicolumn{2}{|c|}{$1.00 * \star \star \star * \star * *$} \\
\hline APPRO : AS & 49. & -119. & 36. & 1500. & 38772 . & 558. & 2.69 & 515.35 \\
\hline XSID : CODE & XLKQ & XRKQ & & & & & & \\
\hline APPRO: AS & -1 & 23. & 1762 & & & & & \\
\hline
\end{tabular}

SECOND USER DEFINED TABLE.

\begin{tabular}{|c|c|c|c|c|c|c|c|c|c|}
\hline XSID: CODE & CRWS & FR\# & YMIN & YMAX & $\mathrm{HF}$ & $\mathrm{HO}$ & VHD & EGL & WS \\
\hline EITX:XS & 509.83 & 91 & 05.15 & 528.32 * & $* * * *$ & *** & 0.72 & 10.61 & 89 \\
\hline GUL & $\star \star \star \star \star \star \star \star \star *$ & 60 & 5.24 & 8.41 & 0.33 & 0.00 & 0.38 & .93 & 55 \\
\hline BRIDG : BR & 511.68 & 1.00 & 504.50 & $515.46 *$ & $* \star \star \star \star * *$ & $\star \star \star \star$ & 2.67 & 514.35 & 511.68 \\
\hline RDWAY : RG & $\star \star \star \star \star * \star * \star * * * *$ & $\star \star \star \star \star *$ & 516.54 & 529.84 * & $\approx * \star \star \star \star *$ & *** & $\star * * * * *$ & $* \star \star \star \star * \star * * *$ & $\star \star \star \star \star \star * \star *$ \\
\hline PPRO : AS & 510.54 & 0.27 & 505.47 & 527.72 & 0.04 & 1.10 & 0.13 & 515.49 & 515.35 \\
\hline
\end{tabular}




\section{APPENDIX C:}

\section{BED-MATERIAL PARTICLE-SIZE DISTRIBUTION}




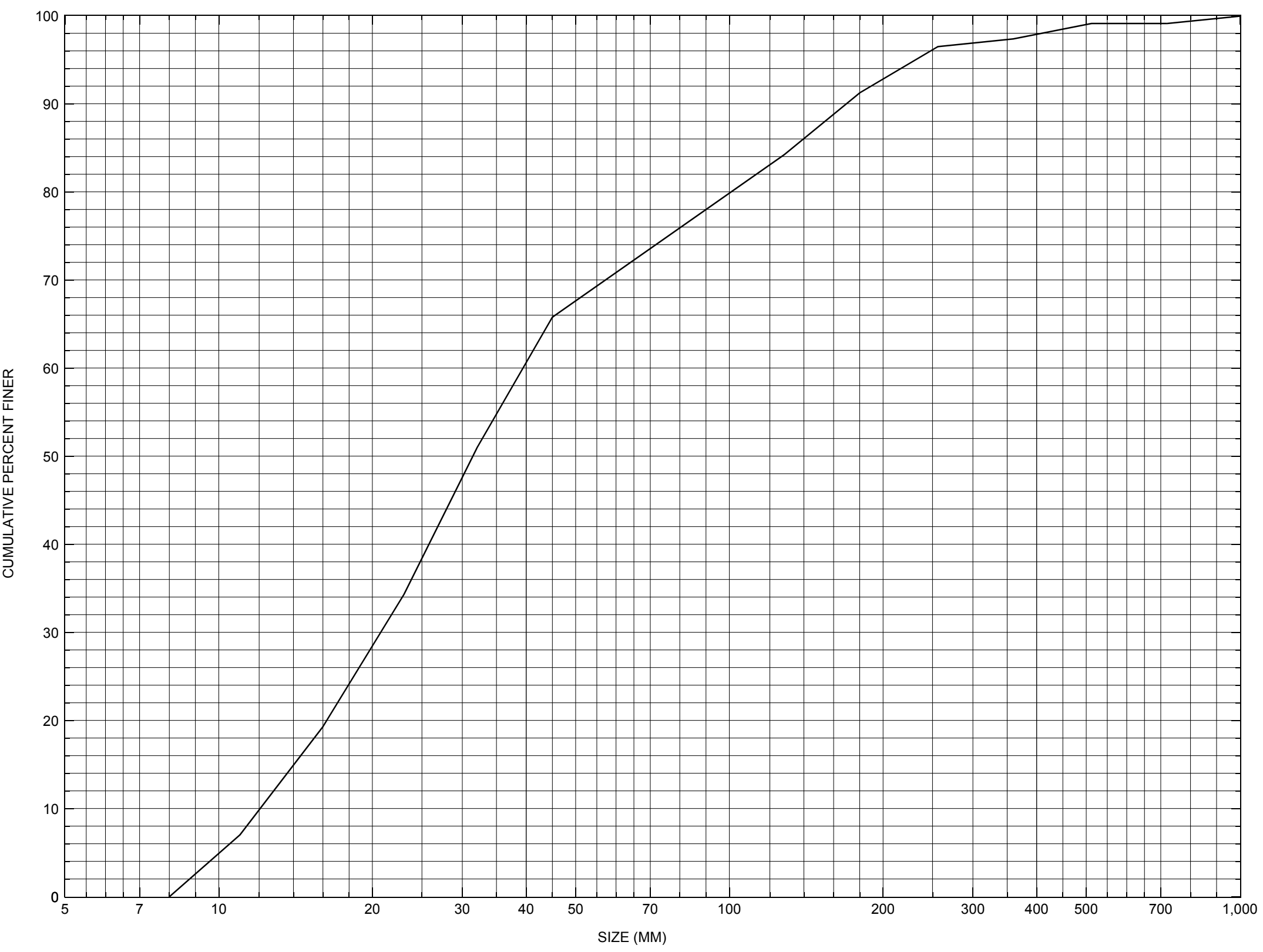

Appendix C. Bed material particle-size distribution for a pebble count in the channel approach of structure ANDOVT00110035, in Andover, Vermont. 


\section{APPENDIX D: \\ HISTORICAL DATA FORM}




\section{Structure Number ANDOVT00110035}

\section{General Location Descriptive}

Data collected by (First Initial, Full last name) $\mathbf{M}$. IVANOFF

Date $(M M / D D / Y Y) \_\mathbf{0 3} / \underline{\mathbf{2 8}} / \underline{\mathbf{9 5}}$

Highway District Number (I - 2; nn) $\mathbf{0 2}$

Town (FIPS place code; I - 4; nnnnn) $\mathbf{0 1 3 0 0}$

Waterway (I - 6) MIDDLE BR WILLIAMS RIVER

Route Number VT 11

Topographic Map Saxtons River

Latitude (I - 16; nnnn.n) $\mathbf{4 3 1 4 6}$
County (FIPS county code; I - 3; nnn)

Mile marker (I - 11; nnn.nnn) $\mathbf{0 0 0 8 1 0}$

Road Name (I - 7): -

Vicinity (I - 9) 2.0 MI E JCT VT 121

Hydrologic Unit Code: $\mathbf{0 1 0 8 0 1 0 7}$

Longitude (i - 17; nnnnn.n) $\mathbf{7 2 4 2 3}$

\section{Select Federal Inventory Codes}

FHWA Structure Number $(I-8) \underline{20001600351401}$

Maintenance responsibility $(I-21 ; n n) \quad \mathbf{0 1} \quad$ Maximum span length $(I-48 ; n n n n) \underline{\mathbf{0 0 2 4}}$

Year built (I - 27; YYYY) 1929

Structure length (I - 49; nnnnnn) $\underline{\mathbf{0 0 0 0 2 8}}$

Average daily traffic, ADT (I - 29; nnnnnn) $\underline{002736}$

Deck Width (I - 52; nn.n) $\mathbf{3 1 2}$

Year of ADT (I - 30; YY) $\mathbf{9 2}$

Channel \& Protection $(I-61 ; n) \underline{7}$

Opening skew to Roadway $(I-34 ; n n) \quad \mathbf{2 0}$

Waterway adequacy $(I-71 ; n) \underline{5}$

Operational status $(I-41 ; X) \quad \mathbf{A}$

Underwater Inspection Frequency $(I-92 B ; X Y Y) \_\mathbf{N}$

Structure type (I - 43; nnn) 104

Year Reconstructed (I - 106) 1970

Approach span structure type (I - 44; nnn) $\mathbf{0 0 0}$ Clear span (nnn.n ft)

Number of spans (I - 45; nnn) $\mathbf{0 0 1}$

Vertical clearance from streambed (nnn.n ft) $\underline{9.5}$

Number of approach spans (I - 46; nnnn) $\mathbf{0 0 0 0}$

Waterway of full opening ( $\left.n n n . n \mathrm{ft}^{2}\right)$

Comments:

The structural inspection report of $11 / 10 / 93$ indicates the structure is a concrete T-beam bridge with an asphalt surface. Some slight settlement of the road embankments is reported behind the abutment walls. The structure was widened along each side in 1970 using steel stringers. The upstream right wingwall end has some minor spalling noted. The waterway makes a sharp turn into the structure and there is some very minor localized scour at the upstream end of the left abutment. The streambed consists of stone and gravel with a few random boulders. Very minor bank erosion is reported. The stone fill is normal stone and boulder. 


\section{Bridge Hydrologic Data}

Is there hydrologic data available? $\underline{\mathbf{N}}$ if No, type ctrl-n $h \quad$ VTAOT Drainage area $\left(m i^{2}\right)$ : -

Terrain character:

Stream character \& type: -

Streambed material:

Discharge Data (cfs):

$$
\begin{aligned}
& Q_{2.33}- \\
& Q_{50}-
\end{aligned}
$$

Record flood date $(M M / D D / Y Y)$ :

Estimated Discharge (cfs): Ice conditions (Heavy, Moderate, Light) : -

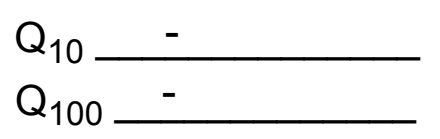

$$
\begin{aligned}
& Q_{25}- \\
& Q_{500}-
\end{aligned}
$$

Water surface elevation $(f t):-$

The stage increases to maximum highwater elevation (Rapidly, Not rapidly):

The stream response is (Flashy, Not flashy):

Describe any significant site conditions upstream or downstream that may influence the stream's stage: -

Watershed storage area (in percent): _ _ \%

The watershed storage area is: - (1-mainly at the headwaters; 2- uniformly distributed; 3-immediatly upstream oi the site)

Water Surface Elevation Estimates for Existing Structure:

\begin{tabular}{|l|l|l|l|l|l|}
\hline Peak discharge frequency & $Q_{2.33}$ & $Q_{10}$ & $Q_{25}$ & $Q_{50}$ & $Q_{100}$ \\
Water surface elevation (ft)) & - & - & - & - & - \\
Velocity (ft/sec) & - & - & - & - & - \\
\hline
\end{tabular}

Long term stream bed changes: -

Is the roadway overtopped below the $\mathrm{Q}_{100}$ ? (Yes, No, Unknown): $\mathbf{U}$ Frequency: Relief Elevation (ft): Discharge over roadway at $Q_{100}\left(f^{3} / \mathrm{sec}\right)$ :

Are there other structures nearby? (Yes, No, Unknown): $\underline{\mathbf{U}}$ Upstream distance (miles): Town: If No or Unknown, type ctrl-n os Highway No. : Structure No. : Year Built:

Clear span (ft): Clear Height $(f t)$ : Full Waterway $\left(f^{2}\right)$ : 
Downstream distance (miles): Town: Year Built:

Highway No. : Structure No. : Structure Type:

Clear span $(f t):$ Clear Height $(f t)$ : Full Waterway $\left(f^{2}\right):$

Comments:

\section{USGS Watershed Data}

Watershed Hydrographic Data

Drainage area (DA)

4.65 $\mathrm{mi}^{2}$

Watershed storage (ST)

Bridge site elevation 1280 $\mathrm{ft}$ $\%$

Main channel length 4.13 $\mathrm{mi}$ $10 \%$ channel length elevation 1332 $\mathrm{ft} \quad 85 \%$ channel length elevation $\mathrm{ft}$

Main channel slope $(S)$

(S) 269.07 $\mathrm{ft} / \mathrm{mi}$

Watershed Precipitation Data

Average site precipitation in Average headwater precipitation in

Maximum 2yr-24hr precipitation event $(124,2)$ in

Average seasonal snowfall (Sn) $\mathrm{ft}$ 


\section{Bridge Plan Data}

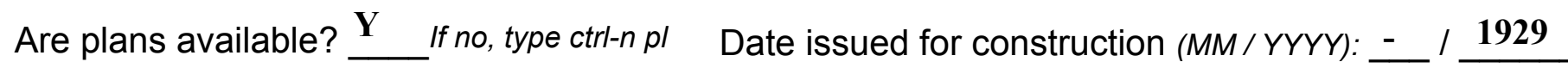
Project Number BMA 6733 Minimum channel bed elevation: 4 483.0

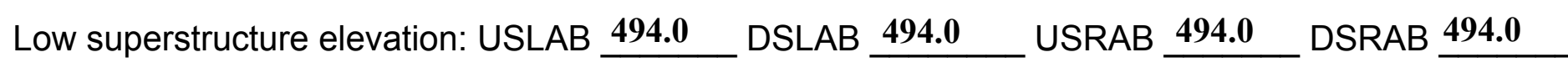
Benchmark location description:

BM\#1, mark on a boulder about 272 feet right bankward on the roadway from the right abutment and 33 feet from the centerline of the roadway perpendicular in a downstream direction near the bottom of a grass slope on the roadway embankment, elevation 500.00.

Reference Point (MSL, Arbitrary, Other): Arbitrary Datum (NAD27, NAD83, Other): Arbitrary Foundation Type: 1 (1-Spreadfooting; 2-Pile; 3- Gravity; 4-Unknown)

If 1 : Footing Thickness $\mathbf{2 . 0} \quad$ Footing bottom elevation: $\underline{\mathbf{4 7 7 . 5}}$

If 2: Pile Type:___ (1-Wood; 2-Steel or metal; 3-Concrete) Approximate pile driven length:

If 3: Footing bottom elevation:

Is boring information available? $\mathbf{N}$ If no, type ctrl- $n$ bi Number of borings taken: _-

Foundation Material Type: $\mathbf{3}$ (1-regolith, 2-bedrock, 3-unknown)

Briefly describe material at foundation bottom elevation or around piles:

Statement on plans: foundations are set in heavy gravel.

Comments:

The plans that exist are for the original T-beam bridge. The structure was rehabilitated in 1970, according to structure records, by widening the upstream and downstream sides (plans not found). Benchmark information is based on the original structure. Other points on the plans with an elevation: 1) The point on the streamward edge, top of concrete at the upstream end of the upstream left wingwall, elevation 494.5. 2) The point at the above described location on the downstream right wingwall, elevation 487.5. 


\section{Cross-sectional Data}

Is cross-sectional data available? $\mathbf{N}$ If no, type ctrl-n xs

Source (FEMA, VTAOT, Other)? -

Comments:

\section{NO CROSS SECTION INFORMATION}

\begin{tabular}{|l|l|l|l|l|l|l|l|l|l|l|l|}
\hline Station & - & - & - & - & - & - & - & - & - & - & - \\
\hline Feature & - & - & - & - & - & - & - & - & - & - & - \\
\hline $\begin{array}{l}\text { Low chord } \\
\text { elevation }\end{array}$ & - & - & - & - & - & - & - & - & - & - & - \\
\hline $\begin{array}{l}\text { Bed } \\
\text { elevation }\end{array}$ & - & - & - & - & - & - & - & - & - & - & - \\
\hline $\begin{array}{l}\text { Low chord } \\
\text { to bed }\end{array}$ & - & - & - & - & - & - & - & - & - & - & - \\
\hline Station & - & - & - & - & - & - & - & - & - & - & - \\
\hline Feature & - & - & - & - & - & - & - & - & - & - & - \\
\hline $\begin{array}{l}\text { Low chord } \\
\text { elevation }\end{array}$ & - & - & - & - & - & - & - & - & - & - & - \\
\hline $\begin{array}{l}\text { Bed } \\
\text { elevation }\end{array}$ & - & - & - & - & - & - & - & - & - & - & - \\
\hline $\begin{array}{l}\text { Low chord } \\
\text { to bed }\end{array}$ & - & - & - & - & - & - & - & - & - & - & - \\
\hline
\end{tabular}

Source (FEMA, VTAOT, Other)?

Comments: NO CROSS SECTION INFORMATION

\begin{tabular}{|l|l|l|l|l|l|l|l|l|l|l|l|}
\hline Station & - & - & - & - & - & - & - & - & - & - & - \\
\hline Feature & - & - & - & - & - & - & - & - & - & - & - \\
\hline $\begin{array}{l}\text { Low chord } \\
\text { elevation }\end{array}$ & - & - & - & - & - & - & - & - & - & - & - \\
\hline $\begin{array}{l}\text { Bed } \\
\text { elevation }\end{array}$ & - & - & - & - & - & - & - & - & - & - & - \\
\hline $\begin{array}{l}\text { Low chord } \\
\text { to bed }\end{array}$ & - & - & - & - & - & - & - & - & - & - & - \\
\hline Station & - & - & - & - & - & - & - & - & - & - & - \\
\hline Feature & - & - & - & - & - & - & - & - & - & - & - \\
\hline $\begin{array}{l}\text { Low chord } \\
\text { elevation }\end{array}$ & - & - & - & - & - & - & - & - & - & - & - \\
\hline $\begin{array}{l}\text { Bed } \\
\text { elevation }\end{array}$ & - & - & - & - & - & - & - & - & - & - & - \\
\hline $\begin{array}{l}\text { Low chord } \\
\text { to bed }\end{array}$ & - & - & - & - & - & - & - & - & - & - & - \\
\hline
\end{tabular}




\section{APPENDIX E: \\ LEVEL I DATA FORM}


U. S. Geological Survey

Bridge Field Data Collection and Processing Form

Qa/Qc Check by: $\mathbf{R B}$ Date: $09 / \mathbf{2 4 / 9 6}$

\section{Structure Number ANDOVT00110035}

Computerized by: $\underline{\mathbf{R B}}$ Date: $09 / 25 / 96$

Reviewd by: $\quad$ RB Date: $\underline{01 / 13 / 98}$

\section{A. General Location Descriptive}

1. Data collected by (First Initial, Full last name) E. WILD

2. Highway District Number $\mathbf{0 2}$

Mile marker 000810

County WINDSOR (027)

Waterway $(l$ - 6) MIDDLE BR. WILLIAMS RIVER

Town ANDOVER (01300)

Route Number VT11

Road Name -

Hydrologic Unit Code: $\mathbf{0 1 0 8 0 1 0 7}$

3. Descriptive comments:

This bridge is located 2.0 miles east of the junction with VT 121, also, 0.2 miles west of TH35, Gates Road, and 600 ft southwest of ANDO036.

\section{B. Bridge Deck Observations}
4. Surface cover... LBUS 6
RBUS 5
LBDS 6
RBDS 5
Overall 6

(2b us,ds,lb,rb: 1- Urban; 2- Suburban; 3- Row crops; 4- Pasture; 5- Shrub- and brushland; 6- Forest; 7- Wetland)
5. Ambient water surface... US 2
UB 1
DS 1
(1- pool; 2- riffle)

6. Bridge structure type 1 (1- single span; 2- multiple span; 3- single arch; 4- multiple arch; 5- cylindrical culvert; 6- box culvert; or 7- other)
7. Bridge length $\underline{28}$
(feet)
Span length $\underline{\mathbf{2 4}}$
(feet)
Bridge width $\underline{\mathbf{3 1 . 2}}$ (feet)

\section{Road approach to bridge:}
8. LB $\mathbf{0}$ RB $\mathbf{0}$
( 0 even, 1- lower, 2- higher)
9. LB
RB 1
(1- Paved, 2- Not paved)

10. Embankment slope (run / rise in feet / foot)

US left

US right

\begin{tabular}{|c|c|c|c|}
\hline \multicolumn{2}{|c|}{ Protection } & \multirow{2}{*}{ 13.Erosion } & 14.Severity \\
\hline 11.Type & 12.Cond. & $\underline{\mathbf{3}}$ & $\underline{\mathbf{2}}$ \\
\hline $\mathbf{2}$ & $\mathbf{2}$ & $\underline{\mathbf{2}}$ & $\underline{\mathbf{2}}$ \\
\hline $\mathbf{1}$ & $\mathbf{2}$ & $\underline{\mathbf{2}}$ & $\underline{\mathbf{1}}$ \\
\hline $\mathbf{1}$ & $\mathbf{1}$ & $\underline{\mathbf{2}}$ & $\mathbf{1}$ \\
\hline $\mathbf{2}$ & $\mathbf{1}$ & $\underline{\mathbf{2}}$ \\
\hline
\end{tabular}

Bank protection types: 0- none; 1- < 12 inches,

2- $<36$ inches; $3-<48$ inches;

4- < 60 inches; 5- wall / artificial levee

Bank protection conditions: 1- good; 2- slumped;

3- eroded; 4- failed

Erosion: 0 - none; 1- channel erosion; 2 -

road wash; 3- both; 4- other

Erosion Severity: 0 - none; 1- slight; 2- moderate; 3- severe

\section{Channel approach to bridge (BF):}

15. Angle of approach: $\mathbf{1 0}$

16. Bridge skew: 45

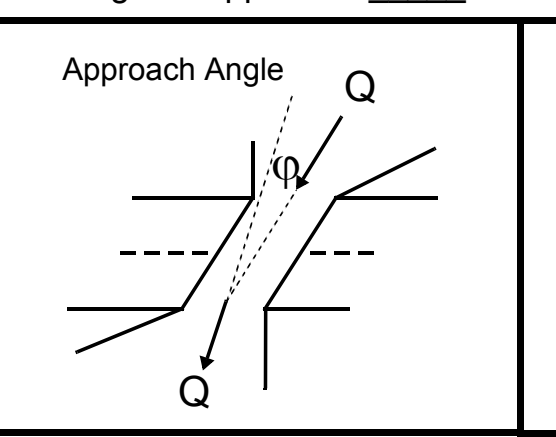

17. Channel impact zone 1:

Where? LB $(L B, R B)$

Range? 140 feet US

Channel impact zone 2:

Where? RB (LB, RB) Bridge Skew Angle

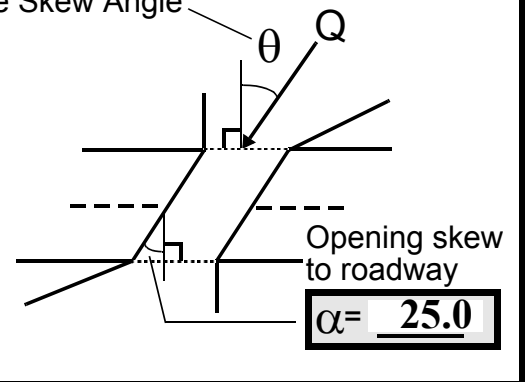

Range? 42 feet DS

Exist? $\mathbf{Y}(Y$ or $N)$

Severity 1

$U B, D S)$ to 3 feet $\mathbf{U B}$

Exist? $\mathbf{Y}(\mathrm{Y}$ or $N)$

Severity 1

Impact Severity: 0- none to very slight; 1- Slight; 2- Moderate; 3- Severe 
18. Bridge Type: 1a

1a- Vertical abutments with wingwalls

$1 \mathrm{~b}$ - Vertical abutments without wingwalls

2- Vertical abutments and wingwalls, sloping embankment Wingwalls parallel to abut. face

3- Spill through abutments

4- Sloping embankment, vertical wingwalls and abutments

Wingwall angle less than $90^{\circ}$.

19. Bridge Deck Comments (surface cover variations, measured bridge and span lengths, bridge type variations, approach overflow width, etc.)

4. The right bank surface cover is trees and brush. The left bank surface cover is trees. State Route 11 crosses the US right bank and the DS left bank.

7. The values are from the VTAOT files. The measured bridge dimensions are the same.

18. The US wingwalls are type $1 \mathrm{a}$ and the DS wingwalls are type 4.

\section{Upstream Channel Assessment}

\begin{tabular}{|c|c|c|c|c|c|c|c|c|c|c|c|}
\hline & \multicolumn{4}{|c|}{ 21. Bank height (BF) 22. Bank angle (BF) } & \multicolumn{2}{|c|}{ 26. \% Veg. cover (BF) } & \multicolumn{3}{|c|}{ 27. Bank material (BF) } & \multicolumn{2}{|c|}{ 28. Bank erosion (BF } \\
\hline 20. SRD & LB & RB & LB & RB & LB & RB & LB & RB & & LB & $\mathrm{RB}$ \\
\hline 34.0 & 6.0 & & & 6.5 & 3 & 3 & 234 & 234 & & 2 & 1 \\
\hline 23. Bank v & dth & & 24. & inel width & 30.0 & 25. Tha & Iweg dept & 75.5 & & Bed Material & 435 \\
\hline 30 . Bank p & otectic & pe: & LB $\underline{0}$ & RB $\underline{\mathbf{0}}$ & & 31. Bank pr & otection c & dition: & LB - & $\mathrm{RB}$ - & \\
\hline $\begin{array}{l}\text { SRD - Se } \\
\text { Bed and } \\
\text { Bank Ero } \\
\text { Bank pro } \\
\text { Bank pro }\end{array}$ & $\begin{array}{l}\text { on } r \\
\text { nk } M \\
\text { n: } 0 \\
\text { tion }\end{array}$ & $\begin{array}{l}\text { evid } \\
0-\end{array}$ & $\begin{array}{l}\text { face } \\
\text { ganics } \\
\text { bble, } \\
1-\text { lig } \\
\text { ent; } 1\end{array}$ & $\begin{array}{l}\% \text { Veget } \\
\text { it / clay, } \\
56 \mathrm{~mm} ; \\
\text { ial; 2- }\end{array}$ & $\begin{array}{l}n(\mathrm{Veg} \\
16 \mathrm{~mm} \\
\text { ulder, } \\
\text { rate fl }\end{array}$ & $\begin{array}{l}: 1-0 \text { to } \\
\text { nd, } 1 / 16 \\
n m ; 6-b \\
- \text { heavy } \\
-<48 \text { ir }\end{array}$ & $\begin{array}{l}\text { \%; 2-2 } \\
\text { nm; 3- } \\
\text { ock; } 7-\end{array}$ & $\begin{array}{l}\% ; 3 \\
\text { h; } 2-6 \\
\text { iade } \\
\text { sting }\end{array}$ & & $75 \% ; 4-76$ & $100 \%$ \\
\hline
\end{tabular}

32. Comments (bank material variation, minor inflows, protection extent, etc.):

At about $135 \mathrm{ft}$ US the US end of a dry channel is close to the left bank. At high flows, the water goes towards the left bank, into this channel, and exits adjacent to the end of the US left wingwall, forming an island. 

feet US (US, UB) to 42 feet DS (US, UB, DS) positioned 25 \%LB to $100 \%$ RB

37. Material: $\mathbf{3 4 5}$

38. Point or side bar comments (Circle Point or Side; Note additional bars, material variation, status, etc.):

The DS end of the point bar is gravel, sand and grass with some small trees. An additional point bar extends from $117 \mathrm{ft}$ US to $58 \mathrm{ft}$ US with the mid-bar distance at $105 \mathrm{ft}$ US where it is $11 \mathrm{ft}$ wide. It is positioned from $50 \% \mathrm{LB}$ to $100 \% \mathrm{RB}$ and is comprised of cobbles, gravel, and boulders.

39. Is a cut-bank present? $\mathbf{N}$ ( $Y$ or if $N$ type ctrl-n $c b)$ 40. Where? - $(L B$ or $R B)$

41. Mid-bank distance: 42. Cut bank extent: feet (US, UB) to feet (US, UB, DS)

43. Bank damage: (1- eroded and/or creep; 2- slip failure; 3- block failure)

44. Cut bank comments (eg. additional cut banks, protection condition, etc.):

NO CUT BANKS

There is a cut bank in the dry channel on the left bank from $60 \mathrm{ft}$ US to $30 \mathrm{ft}$ US. Mid-bank distance is $35 \mathrm{ft}$ US where it is eroded.

\section{Is channel scour present? $\mathbf{N}$ ( $Y$ or if $N$ type ctrl-n cs)}

47. Scour dimensions: Length Width Depth : 46. Mid-scour distance: -

48. Scour comments (eg. additional scour areas, local scouring process, etc.):

\section{NO CHANNEL SCOUR}

49. Are there major confluences? $\mathbf{Y}$ ( $Y$ or if $N$ type ctrl-n $m c)$

51. Confluence 1: Distance 6 Confluence 2: Distance -
52. Enters on $\underline{\mathbf{L B}}$ (LB or RB)

Enters on (LB or $R B)$

54. Confluence comments (eg. confluence name):

The confluence is $6 \mathrm{ft}$ wide and enters perpendicular to the bridge face.

\section{Under Bridge Channel Assessment}

55. Channel restraint (BF)? LB 2

\begin{tabular}{|ccccc|}
\hline \multicolumn{2}{|c|}{ 56. Height (BF) } & \multicolumn{2}{c}{57 Angle (BF) } \\
LB & RB & LB & RB \\
47.0 & & & $\mathbf{1 . 0}$ & \\
\hline
\end{tabular}

58. Bank width (BF) (1- natural bank; 2- abutment; 3- artificial levee)

50. How many? 1

53. Type 2 (1- perennial; 2- ephemeral) Type (1- perennial; 2- ephemeral)

Bed and bank Material: 0- organics; 1- silt / clay, < 1/16mm; 2- sand, 1/16 - 2mm; 3- gravel, 2 - 64mm; 4- cobble, 64 - 256mm; 5- boulder, > 256mm; 6- bedrock; 7- manmade

Bank Erosion: 0- not evident; 1- light fluvial; 2- moderate fluvial; 3- heavy fluvial / mass wasting

64. Comments (bank material variation, minor inflows, protection extent, etc.):

435 
65. Debris and Ice Is there debris accumulation?

(Yor $N)$ 66. Where? $\underline{Y}$

(1- Upstream; 2- At bridge; 3- Both)

67. Debris Potential $\underline{3}$

(1- Low; 2- Moderate; 3- High)

68. Capture Efficiency 2

(1- Low; 2- Moderate; 3- High)

69. Is there evidence of ice build-up? 1 ( $Y$ or $N)$

Ice Blockage Potential $\mathbf{N}$

(1-Low; 2- Moderate; 3- High)

70. Debris and Ice Comments:

1

66. There is debris caught on the island where the stream bends sharply to go under the bridge.

\begin{tabular}{|l|c|c|c|c|c|c|c|c|}
\hline Abutments & $\begin{array}{c}\text { 71. Attack } \\
\angle \mathrm{BF})\end{array}$ & $\begin{array}{c}\text { 72. Slope } \\
(\mathrm{Qmax})\end{array}$ & $\begin{array}{l}\text { 73. Toe } \\
\text { loc. (BF) }\end{array}$ & $\begin{array}{c}\text { 74. Scour } \\
\text { Condition }\end{array}$ & $\begin{array}{c}\text { 75. Scour } \\
\text { depth }\end{array}$ & $\begin{array}{c}\text { 76. Exposure } \\
\text { depth }\end{array}$ & 77. Material & 78. Length \\
\hline LABUT & & $\mathbf{2 5}$ & $\mathbf{9 0}$ & $\mathbf{2}$ & $\mathbf{1}$ & $\mathbf{1 . 5}$ & - & $\mathbf{9 0 . 0}$ \\
\hline RABUT & $\mathbf{1}$ & $\mathbf{0}$ & $\mathbf{9 0}$ & & & $\mathbf{2}$ & $\mathbf{0}$ & $\mathbf{2 1 . 5}$ \\
\hline
\end{tabular}

Pushed: $L B$ or RB

Toe Location (Loc.): 0- even, 1- set back, 2- protrudes

Scour cond.: 0- not evident; 1- evident (comment); 2- footing exposed; 3-undermined footing; 4- piling exposed; 5- settled; 6- failed

Materials: 1- Concrete; 2- Stone masonry or drywall; 3- steel or metal; 4- wood

79. Abutment comments (eg. undermined penetration, unusual scour processes, debris, etc.):

-

1

74. There is scour along the US left wingwall and the left abutment. It is $2.75 \mathrm{ft}$ wide and $42 \mathrm{ft}$ in length. Scour depth assumes a thalweg of $0.3 \mathrm{ft}$. The left abutment footing at the middle of the bridge is beneath about $0.1 \mathrm{ft}$ of sand and gravel.

80. Wingwalls:

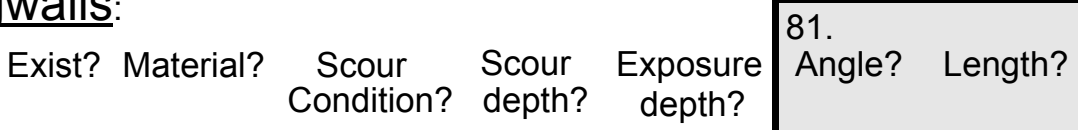

USLWW:

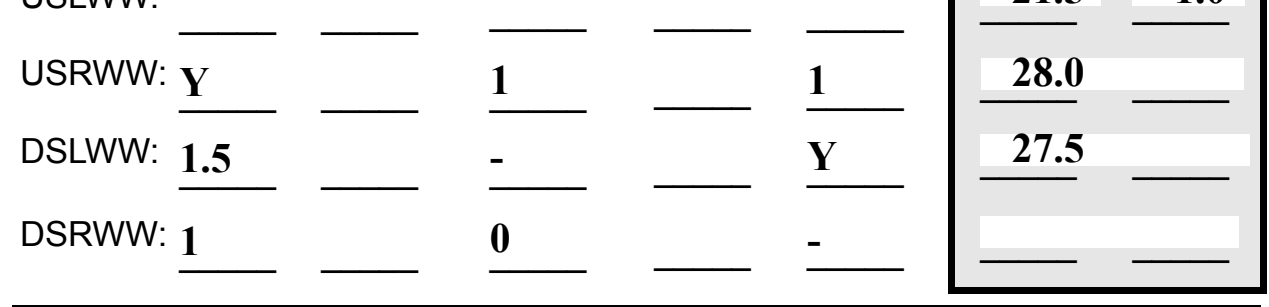

Wingwall materials: 1- Concrete; 2- Stone masonry or drywall; 3- steel or metal; 4- wood

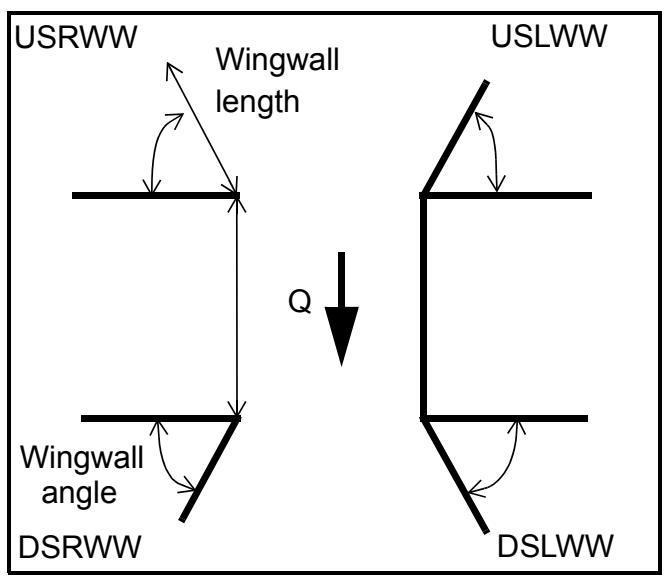

82. Bank / Bridge Protection:

\begin{tabular}{|l|l|l|l|l|l|l|c|c|}
\hline Location & USLWW & USRWW & LABUT & RABUT & LB & RB & DSLWW & DSRWW \\
\hline Type & - & $\mathbf{1}$ & $\mathbf{Y}$ & - & - & - & - & - \\
\hline Condition & $\mathbf{Y}$ & $\mathbf{1 . 7 5}$ & $\mathbf{1}$ & - & - & - & - & - \\
\hline Extent & $\mathbf{1}$ & - & $\mathbf{0}$ & $\mathbf{0}$ & $\mathbf{0}$ & $\mathbf{0}$ & $\mathbf{0}$ & - \\
\hline
\end{tabular}

Bank / Bridge protection types: 0- absent; 1- < 12 inches; 2- < 36 inches; 3- < 48 inches; 4- < 60 inches; 
83. Wingwall and protection comments (eg. undermined penetration, unusual scour processes, etc.):

-
-
-
-
-
0
-
-
0
-
-

\section{Piers:}

84. Are there piers? Th (Y or if $N$ type ctrl-n pr)

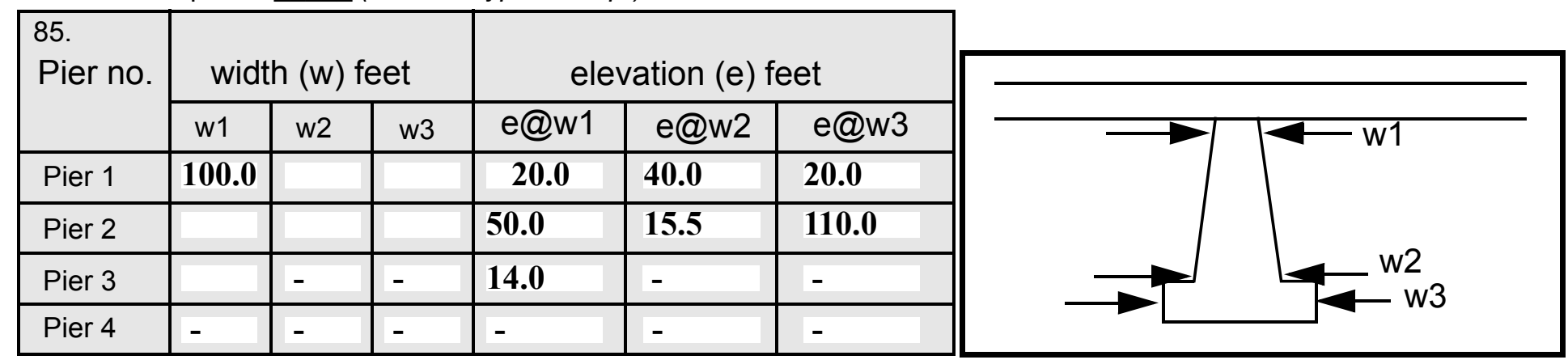

\begin{tabular}{|l|l|l|l|l|}
\hline Level 1 Pier Descr. & \multicolumn{1}{|c|}{1} & \multicolumn{1}{|c|}{2} & \multicolumn{1}{|c|}{3} & \multicolumn{1}{|c|}{ 86. Location (BF) } \\
\hline 87. Type & e & ment & bridge & deck. \\
\hline 88. Material & brid & joint & deck & \\
\hline 89. Shape & ge & s & and & \\
\hline 90. Inclined? & deck & with & the & \\
\hline 91. Attack $\angle$ (BF) & wid- & wing & ment & \\
\hline 92. Pushed & ened & walls & s are & \\
\hline 93. Length (feet) & - & - & - & - \\
\hline 94. \# of piles & so & are & nar- & \\
\hline 95. Cross-members & that & unde & rowe & \\
\hline 96. Scour Condition & all of & rnea & r & \\
\hline 97. Scour depth & the & th & than & N \\
\hline 98. Exposure depth & abut & the & the & - \\
\hline
\end{tabular}

LFP, LTB, LB, MCL, MCM, MCR, RB, RTB, RFP

1- Solid pier, 2- column, 3- bent

1-Wood; 2- concrete; 3- metal; 4- stone

1- Round; 2- Square; 3- Pointed

Y-yes; $N$ - no

$L B$ or $R B$

0- none; 1- laterals; 2- diagonals; 3- both

0- not evident; 1- evident (comment);

2- footing exposed; 3- piling exposed;

4- undermined footing; 5- settled; 6-failed 
99. Pier comments (eg. undermined penetration, protection and protection extent, unusual scour processes, etc.):

-
-
-
-
-
-
-
-
-
-

100.

\section{E. Downstream Channel Assessment}

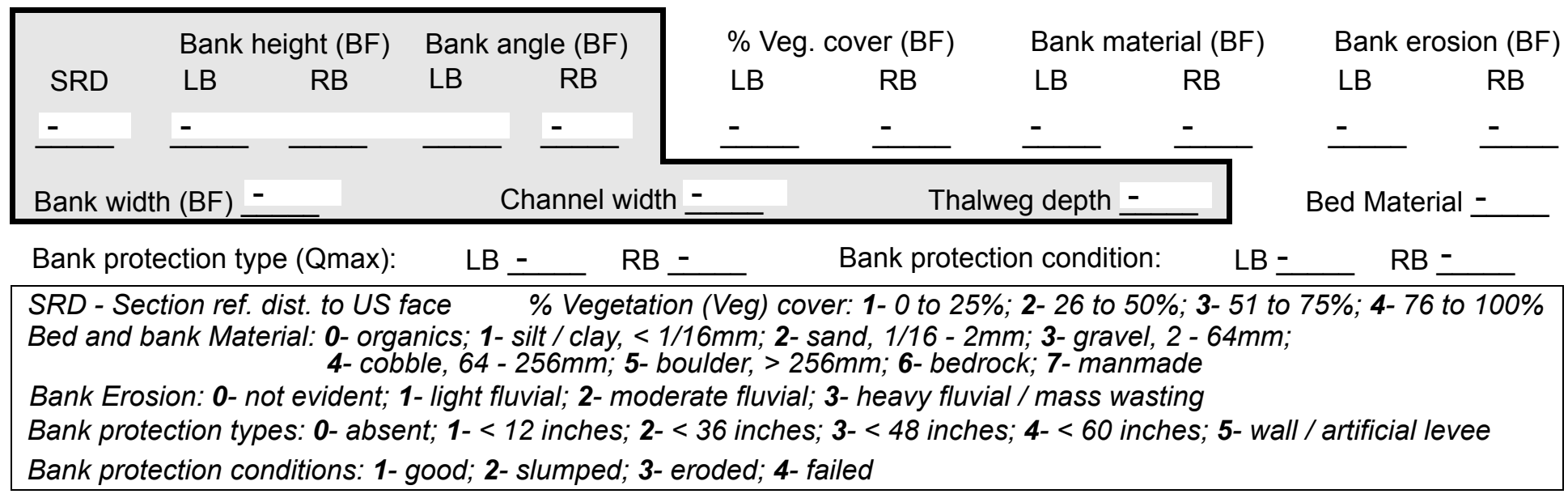

Comments (eg. bank material variation, minor inflows, protection extent, etc.):

$$
-
$$$$
-
$$$$
-
$$$$
-
$$$$
-
$$$$
-
$$$$
-
$$$$
-
$$

$-$

$-$

$-$

$-$

$-$

$-$

$-$

101. Is a drop structure present? _ _ ( or $N$, if $N$ type ctrl-n ds) 102. Distance: ___ feet 103. Drop: -_ feet 104. Structure material: ___ (1- steel sheet pile; 2- wood pile; 3- concrete; 4- other) 105. Drop structure comments (eg. downstream scour depth): 
106. Point/Side bar present? (Y or $N$. if $N$ type ctrl-n pb)Mid-bar distance:

Mid-bar width: -

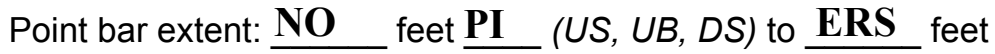
(US, UB, DS) positioned $\%$ LB to $\%$ RB

Material:

Point or side bar comments (Circle Point or Side; note additional bars, material variation, status, etc.):

Is a cut-bank present? (Y or if $N$ type ctrl- $n$ cb) Where? $\underline{\mathbf{3}}$ (LB or RB)

Mid-bank distance: $\mathbf{2}$ Cut bank extent: $\underline{342}$ feet $\underline{\mathbf{3 4 2}}$ (US, UB, DS) to $\underline{1}$ feet $\underline{\mathbf{2}}$ (US, UB, DS)

Bank damage: 435 (1-eroded and/or creep; 2- slip failure; 3- block failure)

Cut bank comments (eg. additional cut banks, protection condition, etc.): o

0

$-$

Is channel scour present? ___ (Y or if $N$ type ctrl-n cs) Mid-scour distance:

Scour dimensions: Length Width Depth:

Positioned $\%$ LB to $\%$ RB

Scour comments (eg. additional scour areas, local scouring process, etc.):

Are there major confluences? Confluence 1: Distance Confluence 2: Distance Enters on Enters on $\underline{\text { NO }}$ (LB or RB) Confluence comments (eg. confluence name):

\section{OP STRUCTURE} ( $Y$ or if $N$ type ctrl-n mc)

How many?

Type $\underline{\mathbf{N}}$ (1- perennial; 2- ephemeral)

Type DR (1- perennial; 2- ephemeral)

\section{F. Geomorphic Channel Assessment}

107. Stage of reach evolution
1- Constructed

2- Stable

3- Aggraded

4- Degraded

5- Laterally unstable

6- Vertically and laterally unstable 
108. Evolution comments (Channel evolution not considering bridge effects; See HEC-20, Figure 1 for geomorphic descriptors):

Y
107
9
76
DS
125
DS
0
30
234




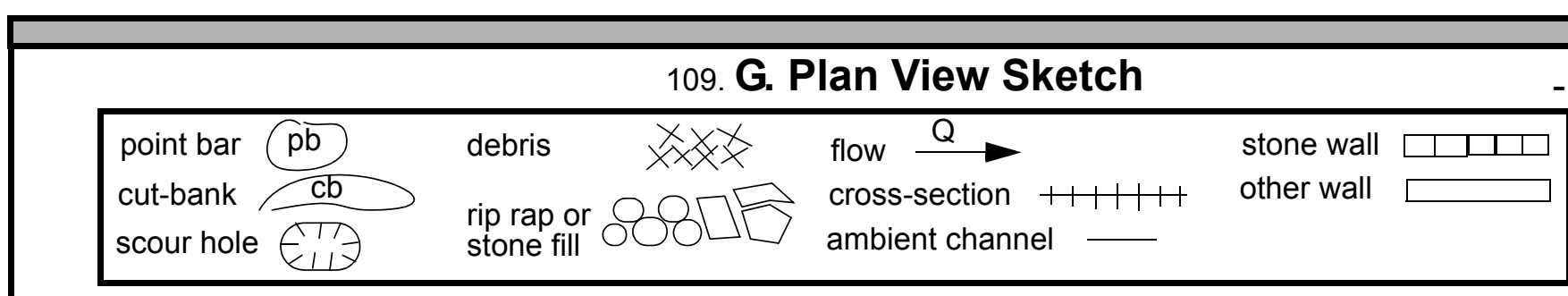


APPENDIX F:

SCOUR COMPUTATIONS 
SCOUR COMPUTATIONS

\begin{tabular}{|c|c|c|c|}
\hline Structure Number: ANDOVT00110035 & & Town: & ANDOVER \\
\hline Road Number: & & County: & WINDSOR \\
\hline Stream: MIDDLE BRANCH WILLIAMS RI & & & \\
\hline Initials RLB & Checked: & MAI & \\
\hline nalysis of contraction scour, li & bed or $\mathrm{c}$ - & lear wa & \\
\hline $\begin{array}{l}\text { Critical Velocity of Bed Material } \\
\text { VC=11.21*y^^0.1667*D50^0.33 with S } \\
\text { (Richardson and Davis, 1995, p. } 28\end{array}$ & $\begin{array}{l}\text { converted } \\
=2.65 \\
\text { eq. } 16)\end{array}$ & to Engl & sh units) \\
\hline Approach Section & & & \\
\hline Characteristic & $100 \mathrm{yr}$ & $500 \mathrm{yr}$ & other $\mathrm{Q}$ \\
\hline Total discharge, cfs & 1670 & 2450 & 1500 \\
\hline Main Channel Area, ft2 & 615 & 718 & 486 \\
\hline Left overbank area, ft2 & 210 & 323 & 72 \\
\hline Right overbank area, ft2 & 74 & 263 & 0 \\
\hline Top width main channel, ft & 76 & 76 & 75 \\
\hline Top width L overbank, ft & 82 & 85 & 79 \\
\hline Top width $\mathrm{R}$ overbank, ft & 96 & 181 & 0 \\
\hline D50 of channel, ft & 0.1032 & 0.1032 & 0.1032 \\
\hline D50 left overbank, ft & -- & -- & -- \\
\hline D50 right overbank, ft & -- & -- & -- \\
\hline $\mathrm{Y}_{1}$, average depth, $\mathrm{MC}$, ft & 8.1 & 9.4 & 6.5 \\
\hline y1, average depth, LOB, ft & 2.6 & 3.8 & 0.9 \\
\hline Y1, average depth, ROB, ft & 0.8 & 1.5 & ERR \\
\hline Total conveyance, approach & 64746 & 95170 & 38737 \\
\hline Conveyance, main channel & 55153 & 71368 & 37310 \\
\hline Conveyance, LOB & 8263 & 16623 & 1427 \\
\hline Conveyance, ROB & 1330 & 7180 & 0 \\
\hline Percent discrepancy, conveyance & 0.0000 & -0.0011 & 0.0000 \\
\hline Qm, discharge, MC, cfs & 1422.6 & 1837.3 & 1444.7 \\
\hline Ql, discharge, LOB, Cfs & 213.1 & 427.9 & 55.3 \\
\hline Qr, discharge, ROB, cfs & 34.3 & 184.8 & 0.0 \\
\hline Vm, mean velocity $\mathrm{MC}$, ft/s & 2.3 & 2.6 & 3.0 \\
\hline Vl, mean velocity, LOB, ft/s & 1.0 & 1.3 & 0.8 \\
\hline Vr, mean velocity, ROB, ft/s & 0.5 & 0.7 & ERR \\
\hline Vc-m, crit. velocity, $M C$, ft/s & 7.5 & 7.6 & 7.2 \\
\hline Vc-l, crit. velocity, LOB, ft/s & $\mathrm{ERR}$ & ERR & ERR \\
\hline Vc-r, crit. velocity, ROB, ft/s & $E R R$ & ERR & ERR \\
\hline Results & & & \\
\hline Live-bed(1) or Clear-Water(0) Cont & action Sc & our? & \\
\hline Main Channel & 0 & 0 & 0 \\
\hline Left Overbank & $\mathrm{N} / \mathrm{A}$ & $\mathrm{N} / \mathrm{A}$ & $\mathrm{N} / \mathrm{A}$ \\
\hline Right Overbank & $\mathrm{N} / \mathrm{A}$ & $\mathrm{N} / \mathrm{A}$ & $\mathrm{N} / \mathrm{A}$ \\
\hline
\end{tabular}




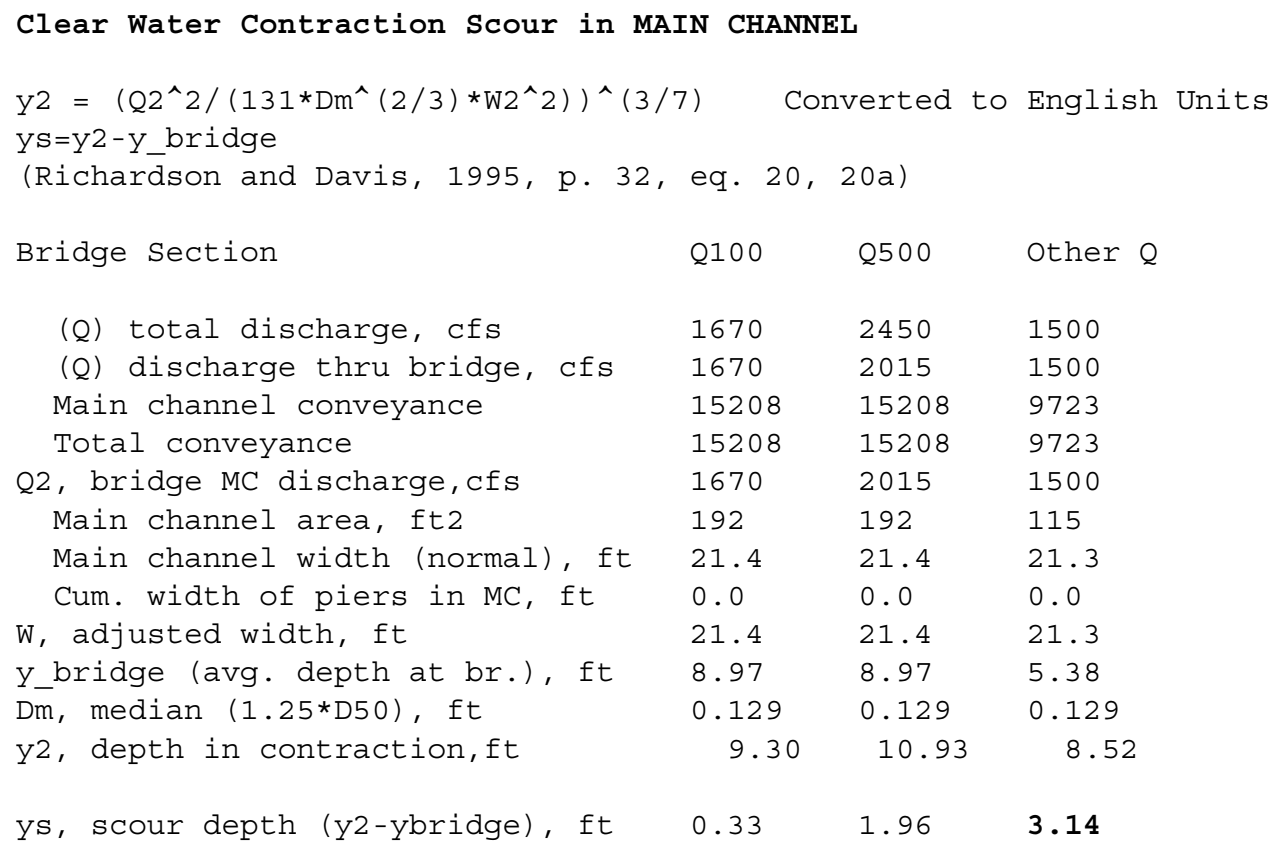

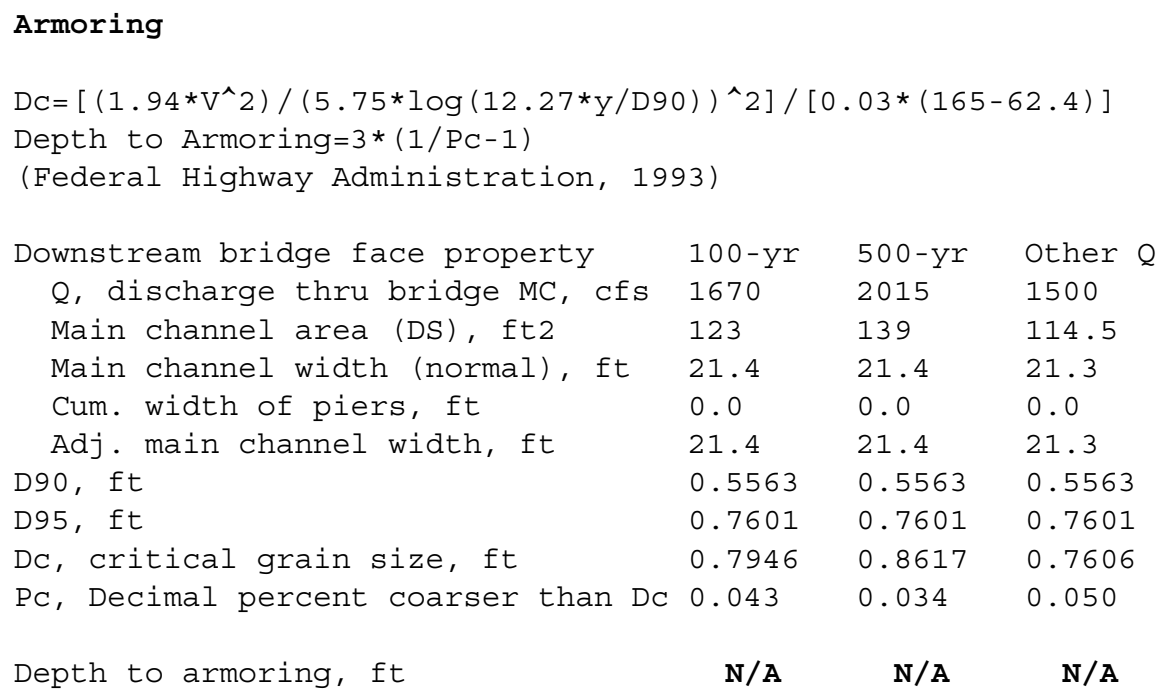




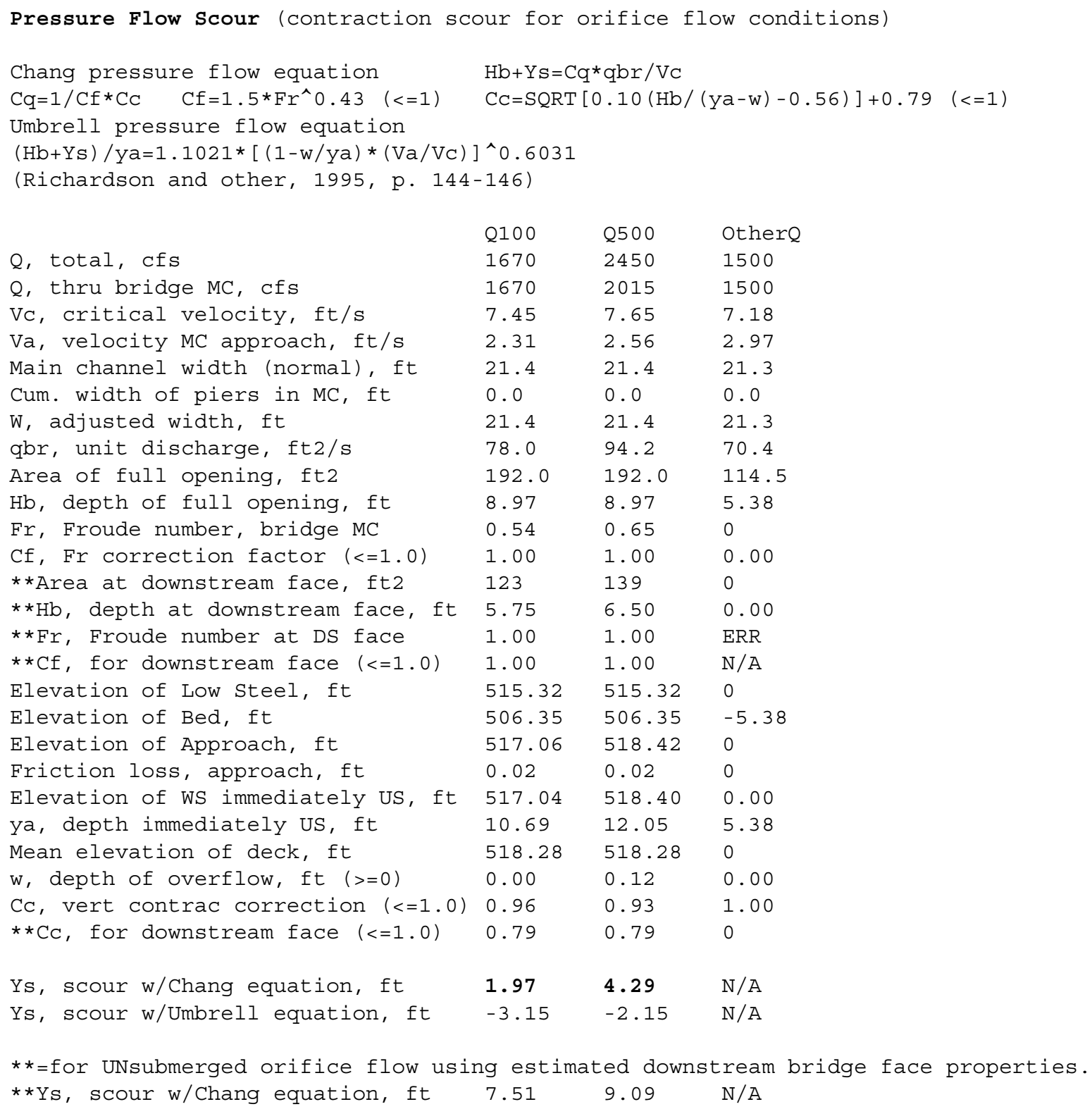


**Ys, scour w/Umbrell equation, ft $0.07 \quad 0.33 \quad$ ERR

In UNsubmerged orifice flow, an adjusted scour depth using the Laursen equation results and the estimated downstream bridge face properties can also be computed (ys=y2-ybridgeDs)

Y2, from Laursen's equation, ft $9.30 \quad 10.93 \quad 8.52$

WSEL at downstream face, ft $512.09 \quad 512.84 \quad 0.00$

Depth at downstream face, ft $\quad 5.75 \quad 6.50 \quad 0.00$

Ys, depth of scour (Laursen), ft $3.56 \quad 4.43 \quad \mathrm{~N} / \mathrm{A}$

\author{
Abutment Scour \\ Froehlich's Abutment Scour \\ $\mathrm{Ys} / \mathrm{Y} 1=2.27 * \mathrm{~K} 1 * \mathrm{~K} 2 *\left(\mathrm{a}^{\prime} / \mathrm{Y} 1\right)^{\wedge} 0.43 * \mathrm{Fr} 1^{\wedge} 0.61+1$ \\ (Richardson and Davis, 1995, p. 48, eq. 28) \\ Characteristic \\ Left Abutment \\ Right Abutment \\ $100 \mathrm{yr} Q 500 \mathrm{yr} Q$ Other Q $100 \mathrm{yr}$ Q $500 \mathrm{yr}$ Q Other Q

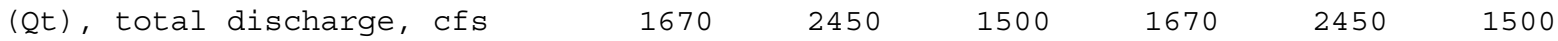 \\ a', abut.length blocking flow, ft $\begin{array}{lllllll}123.2 & 125.9 & 119.8 & 109.7 & 194.7 & 13.1\end{array}$ \\ Ae, area of blocked flow ft2 $\quad \begin{array}{llllll}520.83 & 600.23 & 322.43 & 155.61 & 363.44 & 58.99\end{array}$

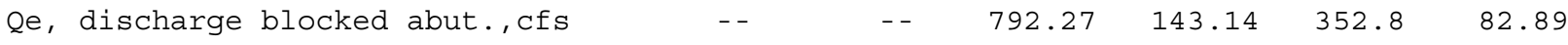 \\ (If using Qtotal_overbank to obtain Ve, leave Qe blank and enter Ve and Fr manually)

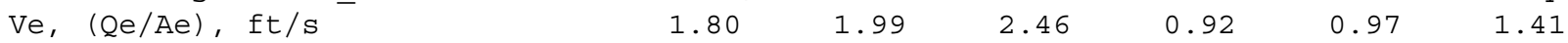

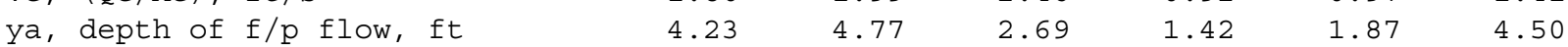 \\ --Coeff., K1, for abut. type (1.0, verti.; 0.82, verti. w/ wingwall; 0.55, spillthru)

$\begin{array}{lllllll}\mathrm{K} 1 & 0.82 & 0.82 & 0.82 & 0.82 & 0.82 & 0.82\end{array}$ \\ --Angle (theta) of embankment (<90 if abut. points DS; >90 if abut. points US) \\ $\begin{array}{lllllll}\text { theta } & 115 & 115 & 115 & 65 & 65 & 65\end{array}$ \\ $\begin{array}{lllllll}\mathrm{K} 2 & 1.03 & 1.03 & 1.03 & 0.96 & 0.96 & 0.96\end{array}$ \\ Fr, froude number f/p flow $\quad \begin{array}{llllll}0.153 & 0.149 & 0.264 & 0.136 & 0.125 & 0.117\end{array}$ \\ $\begin{array}{lllllll}\text { ys, scour depth, ft } & 15.25 & 16.49 & 14.43 & 6.28 & 8.78 & 7.93\end{array}$ \\ HIRE equation ( $a^{\prime} /$ ya $\left.>25\right)$ \\ $\mathrm{ys}=4 * \mathrm{Fr}^{\wedge} 0.33 * \mathrm{Y} 1 * \mathrm{~K} / 0.55$ \\ (Richardson and Davis, 1995, p. 49, eq. 29)
}




\begin{tabular}{|c|c|c|c|c|c|c|}
\hline$a^{\prime}$ (abut length blocked, ft) & 123.2 & 125.9 & 119.8 & 109.7 & 194.7 & 13.1 \\
\hline y1 (depth f/p flow, ft) & 4.23 & 4.77 & 2.69 & 1.42 & 1.87 & 4.50 \\
\hline$a^{\prime} / y^{1}$ & 29.14 & 26.41 & 44.51 & 77.33 & 104.30 & 2.91 \\
\hline Skew correction (p. 49, fig. 16) & 1.06 & 1.06 & 1.06 & 0.92 & 0.92 & 0.92 \\
\hline Froude no. f/p flow & 0.15 & 0.15 & 0.26 & 0.14 & 0.13 & 0.12 \\
\hline Ys w/ corr. factor $\mathrm{K} 1 / 0.55$ : & 1747 & 1953 & $13 \quad 32$ & 490 & 627 & $F R R$ \\
\hline vertical w/ $\mathrm{ww}^{\prime} \mathrm{s}$ & $\begin{array}{l}17.47 \\
14.33\end{array}$ & $\begin{array}{l}19.53 \\
16.02\end{array}$ & $\begin{array}{l}13.32 \\
10.92\end{array}$ & $\begin{array}{l}4.90 \\
4.02\end{array}$ & $\begin{array}{l}6.27 \\
5.14\end{array}$ & $\begin{array}{l}\text { ERR } \\
\text { ERR }\end{array}$ \\
\hline spill-through & 9.61 & 10.74 & 7.32 & 2.69 & 3.45 & ERR \\
\hline Abutment riprap Sizing & & & & & & \\
\hline Isbash Relationship & & & & & & \\
\hline $\begin{array}{l}\mathrm{D} 50=\mathrm{Y}^{*} \mathrm{~K} * \mathrm{Fr}{ }^{\wedge} 2 /(\mathrm{Ss}-1) \text { and } \mathrm{D} 50=\mathrm{Y} * \mathrm{~K} * \\
\text { (Richardson and Davis, 1995, p112 }\end{array}$ & 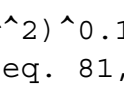 & $(S s-1)$ & & & & \\
\hline Characteristic & Q100 & Q500 & Other $Q$ & Q100 & Q500 & Other $Q$ \\
\hline Fr, Froude Number & 1 & 1 & 1 & 1 & 1 & 1 \\
\hline$y$, depth of flow in bridge, ft & 5.75 & 6.50 & 5.38 & 5.75 & 6.50 & 5.38 \\
\hline Median Stone Diameter for riprap & : left & outment & & right & abutment, & ft \\
\hline Fr< $<0.8$ (vertical abut.) & ERR & ERR & ERR & ERR & ERR & ERR \\
\hline Fr>0.8 (vertical abut.) & 2.40 & 2.72 & 2.25 & 2.40 & 2.72 & 2.25 \\
\hline
\end{tabular}

